\title{
The very strong coastal El Niño in 1925 in the far-eastern Pacific
}

\author{
Ken Takahashi $^{1}$ [D $\cdot$ Alejandra G. Martínez ${ }^{1}$
}

Received: 26 May 2016 / Accepted: 20 April 2017 / Published online: 20 May 2017

(C) The Author(s) 2017. This article is an open access publication

\begin{abstract}
The 1925 El Niño (EN) event was the third strongest in the twentieth century according to its impacts in the far-eastern Pacific (FEP) associated with severe rainfall and flooding in coastal northern Peru and Ecuador in February-April 1925. In this study we gathered and synthesised a large diversity of in situ observations to provide a new assessment of this event from a modern perspective. In contrast to the extreme 1982-1983 and 1997-1998 events, this very strong "coastal El Niño" in early 1925 was characterised by warm conditions in the FEP, but cool conditions elsewhere in the central Pacific. Hydrographic and tide-gauge data indicate that downwelling equatorial Kelvin waves had little role in its initiation. Instead, ship data indicate an abrupt onset of strong northerly winds across the equator and the strengthening/weakening of the intertropical convergence zones (ITCZ) south/north of the equator. Observations indicate lack of external atmospheric forcing by the Panama gap jet and the south Pacific anticyclone and suggest that the coupled ocean-atmosphere feedback
\end{abstract}

This paper is a contribution to the special collection on ENSO Diversity. The special collection aims at improving understanding of the origin, evolution, and impacts of ENSO events that differ in amplitude and spatial patterns, in both observational and modeling contexts, and in the current as well as future climate scenarios. This special collection is coordinated by Antonietta Capotondi, Eric Guilyardi, Ben Kirtman and Sang-Wook Yeh.

Electronic supplementary material The online version of this article (doi:10.1007/s00382-017-3702-1) contains supplementary material, which is available to authorized users.

Ken Takahashi

ken.takahashi@igp.gob.pe

1 Instituto Geofísico del Perú, Calle Badajoz 169, Mayorazgo IV Etapa, Ate Vitarte, 15012 Lima, Peru dynamics associated with the ITCZs, northerly winds, and the north-south SST asymmetry in the FEP lead to the enhancement of the seasonal cycle that produced this EN event. We propose that the cold conditions in the westerncentral equatorial Pacific, through its teleconnection effects on the FEP, helped destabilize the ITCZ and enhanced the meridional ocean-atmosphere feedback, as well as helping produce the very strong coastal rainfall. This is indicated by the nonlinear relation between the Piura river record at $5^{\circ} \mathrm{S}$ and the SST difference between the FEP and the westerncentral equatorial Pacific, a stability proxy. In summary, there are two types of EN events with very strong impacts in the FEP, both apparently associated with nonlinear convective feedbacks but with very different dynamics: the very strong warm ENSO events like 1982-1983 and 19971998, and the very strong "coastal" EN events like 1925.

Keywords Coastal El Niño - ENSO - Eastern Pacific · Wind-evaporation-SST feedback $\cdot$ Peru $\cdot$ Ecuador

\section{Introduction}

"El Niño" was first introduced to the scientific community in reference to the anomalous climatic event that took place in 1891 along the coast of Peru, described as an abnormal intrusion of warm oceanic water from the north, replacing the normally cold coastal-upwelled water and favoring the occurrence of strong rainfall and flooding in the otherwise arid northern coast of Peru (Carranza 1891). The warm southward ocean flow was named "Corriente del Niño" (Child's current) in reference to the weaker climatological version of this current that is normally present after Christmas time (Carrillo 1893). 
(a) Quinn (1992) El Niño magnitude

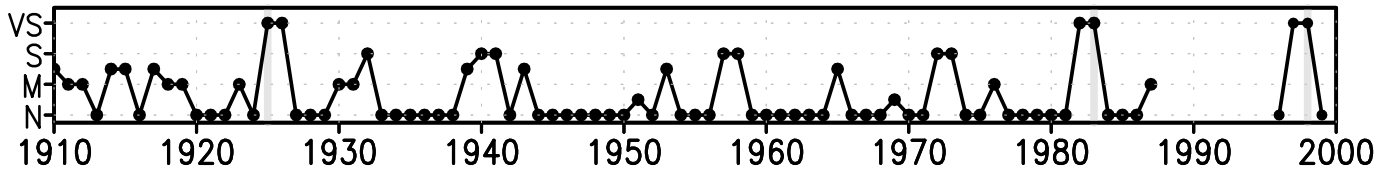

(b) Guayaquil $\left(2.2^{\circ} \mathrm{S}\right)$ annual rainfall $(\mathrm{cm})$

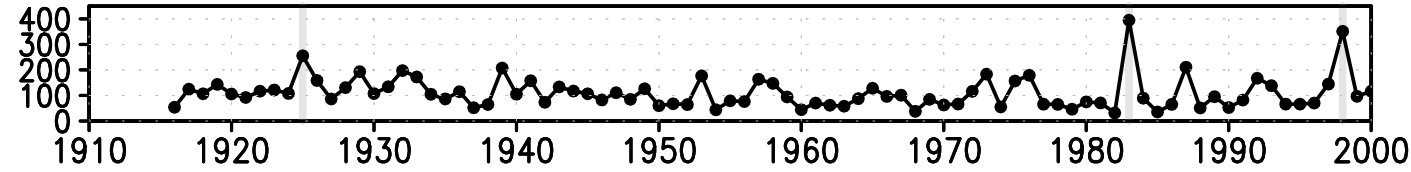

(c) Zaña river $\left(6.8^{\circ} \mathrm{S} @\right.$ El Batan) annual mean discharge $\left(\mathrm{m}^{3} / \mathrm{s}\right)$

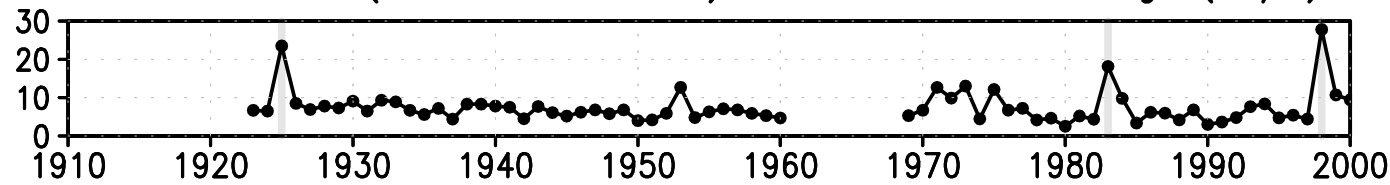

(d) Viru river $\left(8.4^{\circ} \mathrm{S}\right.$ @ Huacapongo) annual mean discharge $\left(\mathrm{m}^{3} / \mathrm{s}\right)$

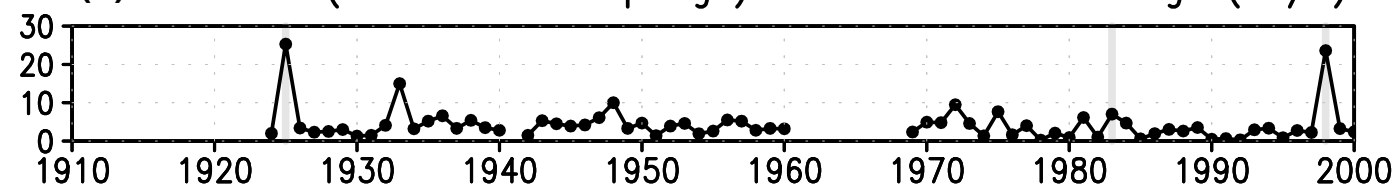

(e) Casma $\left(9.5^{\circ} \mathrm{S}\right)$ annual tree-ring width $(\mathrm{mm})$

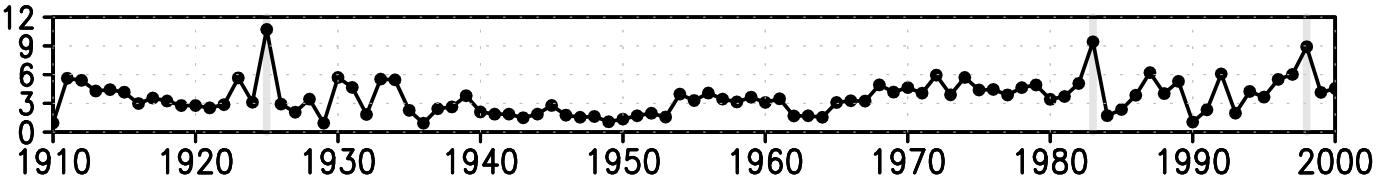

(f) Puerto Chicama $\left(7.7^{\circ} \mathrm{S}\right)$ SST $\left({ }^{\circ} \mathrm{C}\right)$

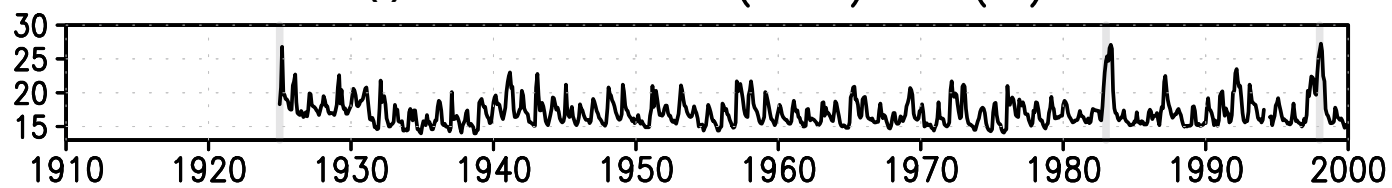

(g) Balboa $\left(9.0^{\circ} \mathrm{N}\right)$ sea surface height anomaly $(\mathrm{cm})$

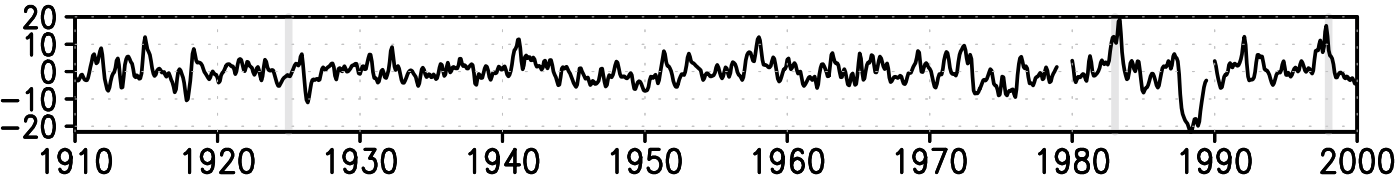

(h) Cold tongue index $\left({ }^{\circ} \mathrm{C}\right)$

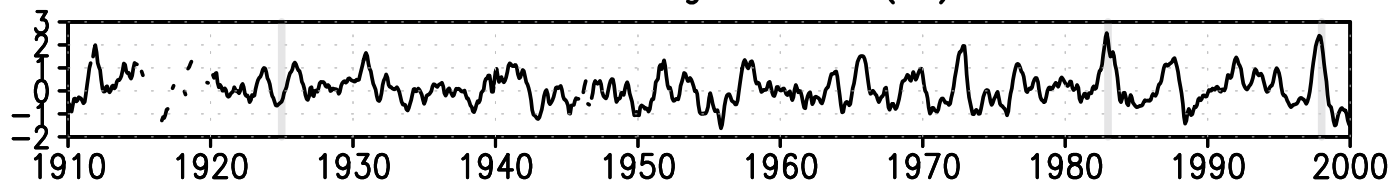

(i) Southern Oscillation Index

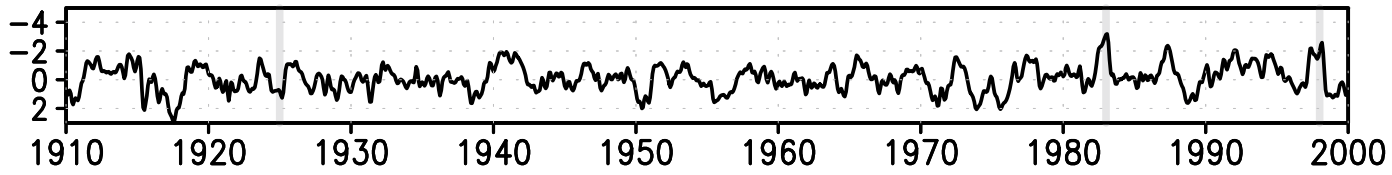


\Fig. 1 El Niño-related indices for the twentieth century: a El Niño magnitudes estimated according to its coastal manifestations (Quinn et al. 1987, updated by Quinn 1992; the 1997-98 event was added), b annual rainfall $(\mathrm{cm})$ in Guayaquil, coastal Ecuador [Sep(-1)Aug(0)], annual mean discharge $\left(\mathrm{m}^{3} / \mathrm{s}\right)$ of the Zaña (c) and d Viru rivers, e Prosopis pallida annual growth ring width (rainfall proxy) from Casma, coastal Peru (Rodriguez et al. 2005), f SST anomaly in Puerto Chicama $\left({ }^{\circ} \mathrm{C}\right), \mathbf{g}$ monthly detrended sea level anomaly $(\mathrm{cm})$ at Balboa, $\mathbf{h}$ the equatorial SST "cold tongue index" $\left({ }^{\circ} \mathrm{C}\right)$, and $\mathbf{i}$ the Southern Oscillation Index (reversed axis). The vertical grey lines correspond to January 1925, 1983, and 1998

Nowadays, the term "El Niño" (EN) is used as shorthand for referring to the warm phase of the large-scale El Niño-Southern Oscillation (ENSO) coupled ocean-atmosphere phenemenon, characterized by anomalously high SST in the central-eastern equatorial Pacific (El Niño) and the reduction of the zonal gradient in sea level pressure across the basin (Southern Oscillation; SO). However, the relation between EN and the SO is not always strong (Deser and Wallace 1987), while the SO has been shown to exist even without the ocean dynamics generally associated with EN (Clement et al. 2011). In practice, the definition of "El Niño" is therefore more a matter of convenience of its users than a strict scientific result (Trenberth 1997).

Although the essential physics of ENSO have been largely identified (e.g. Neelin et al. 1998), recent research is focused on understanding the diversity among the individual events, for which a popular procedure is to classify these based on whether the maximum SST anomalies are predominantly found in the central or eastern Pacific (see review by Capotondi et al. 2015), although this classification is somewhat arbitrary (Takahashi et al. 2011). One possibly "true" distinct type of EN could consist of the extreme EN of 1982-83 and 1997-98, as they appear to correspond to a different dynamical regime from the rest of EN due to the nonlinear activation of deep convection in the cold eastern Pacific (Takahashi et al. 2011; Takahashi and Dewitte 2016). These extreme events have been associated with intense warming in the FEP and disproportionally large rainfall anomalies in the arid western coast of South America (e.g. Woodman 1985, 1999; CAF 2000).

From the perspective of the FEP impacts, the only other "very strong" event in the last century was the 1925-26 EN (Quinn et al. 1987; Fig. 1a) and by several other measures in this region, this EN can be considered among the three strongest, with 1982-83 and 1997-98 (Fig. 1b-f). It was due to the detailed report of this event by Murphy (1926) that "El Niño burst onto the international scientific scene" as a legitimate research topic (Cushman 2004), leading to the discovery by Berlage in 1929 (Cushman 2004) of the statistical relation between EN variability, using an index of rainfall in northern Peru (Eguiguren 1894) as a proxy, and the large-scale atmospheric Southern Oscillation
(Walker 1924), culminating with the concept of ENSO, an essentially coupled ocean-atmosphere phemonenon (Bjerknes 1969).

Although the 1925-26 EN was relatively well documented at the time, some of the ideas that appeared well justified at the time, particularly the role of northerly winds (Schott 1931), have been discarded in the subsequent years with the establishment of the ENSO paradigm in the 1970s and 1980s (Wyrtki 1975; Wallace et al. 1998; Neelin et al. 1998), but without taking a close look at the 1925 EN. Thus, it is timely to revisit the 1925-26 EN in an integrated way, under the light of modern theory and expanded datasets, to recover potentially valuable information and insights on the nature of EN and its diversity.

\section{Data sources and processing}

Monthly series for Puerto Chicama SST $\left(7.7^{\circ} \mathrm{S}, 79.4^{\circ} \mathrm{W}\right.$, 1925-2002), the Piura river discharge (1925-1998), Piura rainfall (1932-2008), and estimated EN magnitudes of Quinn (1992) were obtained from the JISAO data archive (http://jisao.washington.edu/data). The monthly Piura discharge data for March and April 1925 were absent, but these values were estimated as discussed in "Appendix B".

Monthly precipitation for Milagro (1921-1981) and Guayaquil (1915-2000) and mean air temperature for Iquique (1900-1988) from the NOAA NCDC GHCN v2 database were obtained from the IRI Data Library (http:// iridl.ldeo.columbia.edu/). Annual precipitation values were calculated based on the hydrological year from September of the previous year to August. We also used the annual tree-ring width series for an individual of Prosopis pallida (locally known as "algarrobo") in San Rafael, Casma (near the coast at $9.5^{\circ} \mathrm{S}$ ), for $1908-2002$, a proxy for annual precipitation (Rodriguez et al. 2005).

Daily "research quality" mean sea surface height (SSH) for Balboa $\left(8.97^{\circ} \mathrm{N}, 79.57^{\circ} \mathrm{W}, 1907-2012\right)$, on the Pacific side of the Panama Canal, was obtained from the University of Hawaii Sea Level Center (http://uhslc.soest.hawaii. edu/). Monthly means were calculated from this data. The climatology for daily anomalies was calculated using six harmonics of the annual period fitted to the daily data. Anomalies were linearly detrended over the full period.

We used ship-based ocean surface data from the ICOADS database (Worley et al. 2005; Woodruff et al. 2011) in two formats. Firstly, we used the gridded ICOADS 2-degree Enhanced v. 2.5.2 monthly summaries, specifically the mean SST, wind, and cloudiness, which we obtained from the NOAA ESRL website (http://www.esrl. noaa.gov/psd/data/gridded). This dataset consists averages of individual observations over the corresponding $2^{\circ}$ grid boxes, with no spatial interpolation. For broad-scale 
mapping, we constructed 3 month-mean SST and surface wind anomalies during the 1925-26 EN from the gridded monthly ICOADS dataset, with no smoothing or interpolation, limiting the results to those grid cells that contained at least 3 and 10 observations for SST and wind, respectively (wind has stronger high frequency variability). The climatology was constructed from the same data by first averaging temporally and then filling the spatial gaps with a first guess and 9-point smoothing ten times to merge the filled values with the averaged ones. Additionally, we constructed monthly time-series for equatorial segments along four shiptracks that had good data coverage (Fig. 3a).

We also used the individual ship observations from ICOADS Release 2.5 (dataset ds540.0 at NCAR CISL RDA) to produce monthly averages every degree latitude from $9^{\circ}$ to $30^{\circ} \mathrm{S}$ along a well-transited shipping route from Panama to the coasts of Ecuador, Peru and Chile, that started after the opening of the Panama Canal in 1914. Because of this and the onset of World War II in the Pacific, there is good data availability along this track between the years 1920 and 1942. Therefore, unless explicitly indicated, our base period for climatologies for all variables is 1920-1939.

We used a database of approximately 2500 news articles from the Peruvian newspaper "El Comercio" for the period from January 1925 to December 1926, focusing particularly on mentions of meteorological or hydrological phenomena in the coast of Peru (Chang 2014), as well as a database of articles from the newspaper "El Tiempo" from the Piura region (Rojas-Rosas 2014). Numerical meteorological and river discharge data was also retrieved from the newspapers, particularly from the Hipólito Unanue meteorological station in Lima and the daily raingauge data from the Harvard Observatory in Arequipa. Since El Comercio is based in Lima and communications with the northern coast were not in real-time, the news articles often lag the actual events and date and time were seldom reported precisely (Chang 2014), so we indicate the publication date and page number for the relevant newspaper articles in footnotes.

We obtained 18 temperature profiles from the Arcturus expedition (Beebe 1926), which were made in a broad region between Panama and the Galapagos islands between March 30 and June 9, 1925 (Table S1). Four oceanographic profiles of temperature and salinity made in the upper 200 $m$ by a British cruise (NODC code GB012817) along the coast between Ecuador and Panama between April 17-19, 1925 (Table S1) were retrieved from the World Ocean Database 2013 (WOD13; http://www.nodc.noaa.gov/ OC5/SELECT/dbsearch/dbsearch.html). We also digitized selected meteorological, hydrological, and oceanographic data from tables and graphs in Murphy (1926), Zegarra (1926), Berry (1927), Zorell (1929), Bailey (1930), Schott
(1931), Sheppard (1930, 1933), Petersen (1935), Schaeffer et al. (1958), Woodman (1985), and Reparaz (2013).

Two long-term indices used to represent the basin-scale ENSO variability are the cold tongue index (CTI; SST anomaly in $\left.6^{\circ} \mathrm{S}-6^{\circ} \mathrm{N}, 180^{\circ}-90^{\circ} \mathrm{W}, 1845-2011\right)$ from the JISAO data archive (http://jisao.washington.edu/enso/), and the Southern Oscillation Index (SOI; normalized pressure difference between Darwin and Tahiti for 1866-2013) from the CRU website (http://www.cru.uea.ac.uk/cru/data/soi/, based on Ropelewski and Jones 1987).

We complemented the analysis with the following reconstructed observational products, which were trusted only to the extent that they were consistent with actual in situ data: The Hadley Centre Global Sea Ice and Sea Surface Temperature (HadISST) v1.1 (Rayner et al. 2003) and the NOAA Extended Reconstructed SST (ERSST) v3b, Smith et al. 2008) SST products, the SODA 2.2.4 ocean reanalysis (Giese and Ray 2011; http://apdrc.soest.hawaii.edu/), and the NCEP twentieth century Reanalysis v2 (hereafter 20CRv2; Compo et al. (2006, 2011); http://www.esrl.noaa. gov/psd/data/gridded).

\section{Ocean-atmosphere evolution and processes}

The large-scale evolution of the 1925-26 EN followed approximately the development phases of the "canonical El Niño" (Rasmusson and Carpenter 1982, hereafter RC82; Harrison and Larkin 1998). The "onset phase" in November 1924-January 1925 was characterized by anomalously cool conditions and easterly equatorial wind anomalies in the central and eastern equatorial Pacific (Figs. 2a, 3b-e), followed by strong anomalous warming near the coast of South America peaking in March 1925 (Figs. 2b, 3b).

Important departures from the RC82 and HL98 composites are that (1) the warming off Peru took place a couple of months earlier than the corresponding "peak phase" of RC82, so that it coincided with the warmest months (Takahashi 2005) that is most favorable for deep convection (e.g. Takahashi 2004; Huaman and Takahashi 2016), while (2) cool conditions remained in the central-eastern Pacific, expanding to the west, until June 1925 (Figs. 2b, c, 3e), which we later argue is also important for the convective dynamics in the FEP (Sects. 3.2, 3.4).

The warming was confined to the coast in February-March 1925 but then spread westwards, reaching the central Pacific $\left(\sim 170^{\circ} \mathrm{W}\right)$ around August 1925 and peaking by the end of the calendar year (Fig. 3b-e), corresponding to the "mature phase" of the canonical EN (RC82). Westerly wind anomalies started developing in the central Pacific in March 1925 (Fig. 3h-i), indicating the onset of the Bjerknes feedback associated with the FEP warming 
Fig. 2 Seasonal mean SST $\left({ }^{\circ} \mathrm{C}\right)$ from ICOADS (colors, shown only for at least three observations per grid cell) and surface wind vectors anomalies (shown only for at least ten observations per grid cell and a minimum magnitude of $1 \mathrm{~m} / \mathrm{s}$ ). Also shown is the SST anomaly reconstruction HadISST 1.1 (contours; interval: $0.5^{\circ} \mathrm{C}$, slight smoothing). The averaging periods are indicated in each panel (a) Nov 1924-Jan 1925

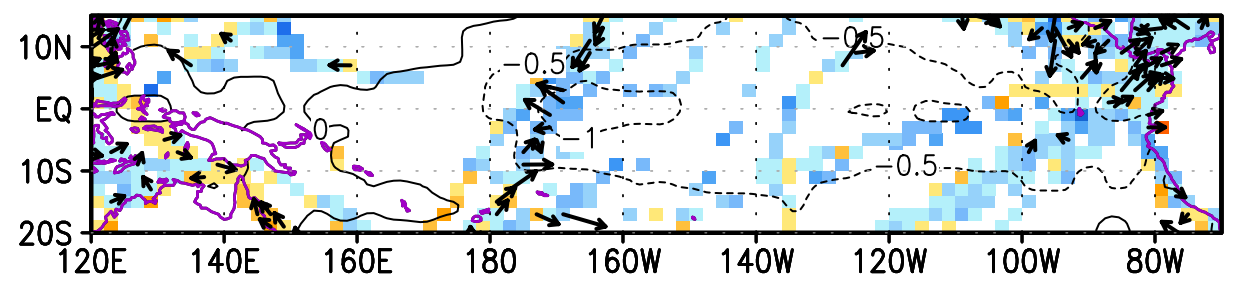

(b) Feb-Apr 1925

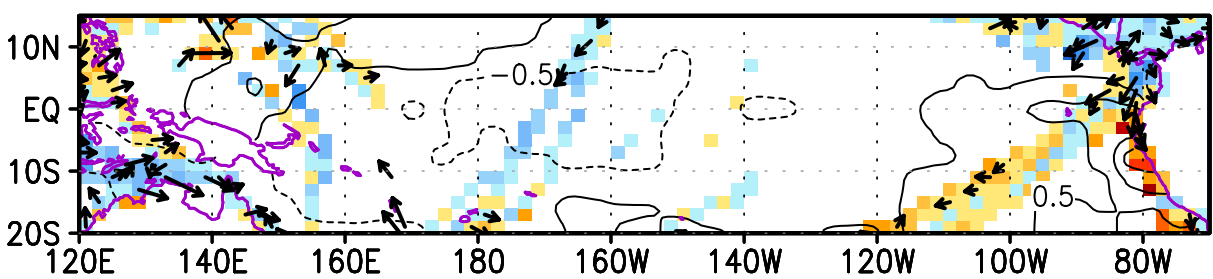

(c) May-Jul 1925

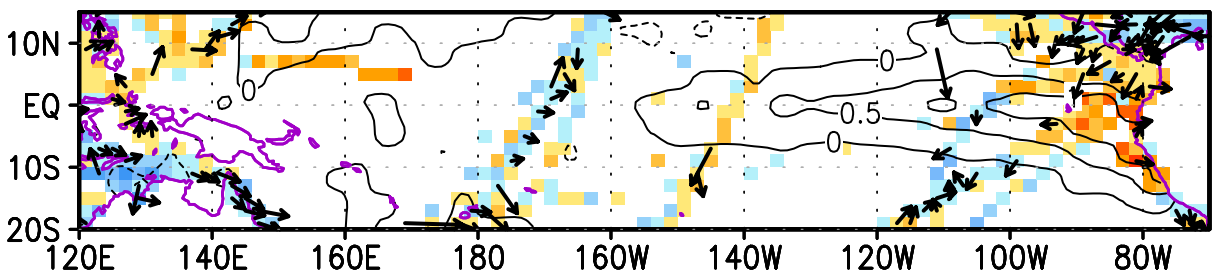

(d) Aug-Oct 1925

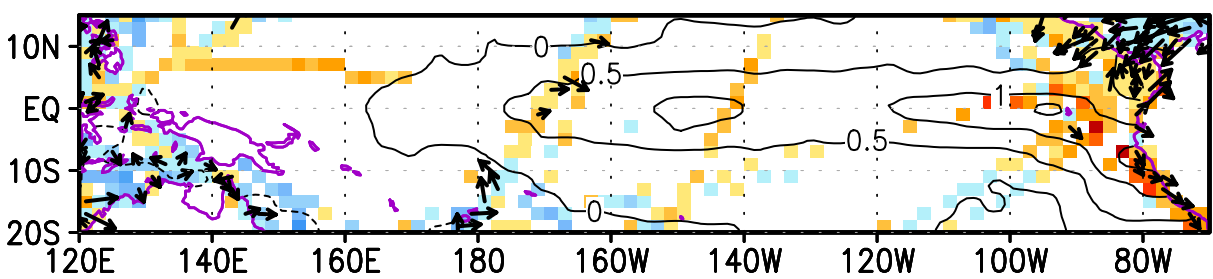

(e) Nov 1925-Jan 1926

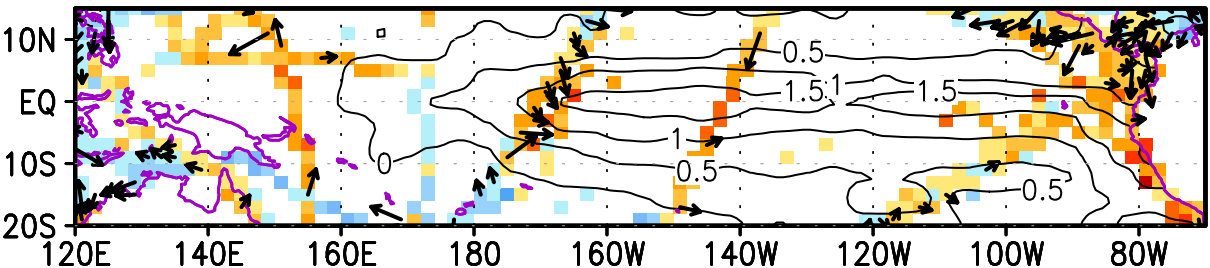

(f) Feb-Apr 1926

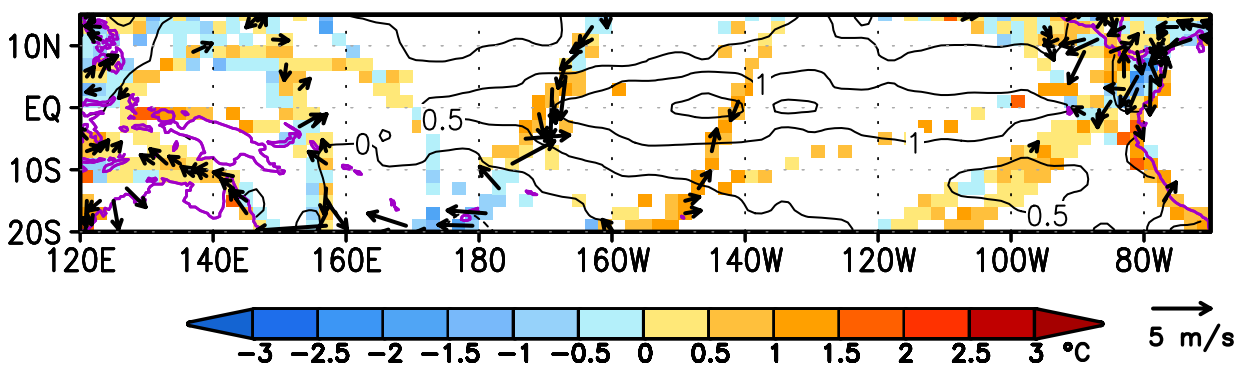


(a) Ship track indices

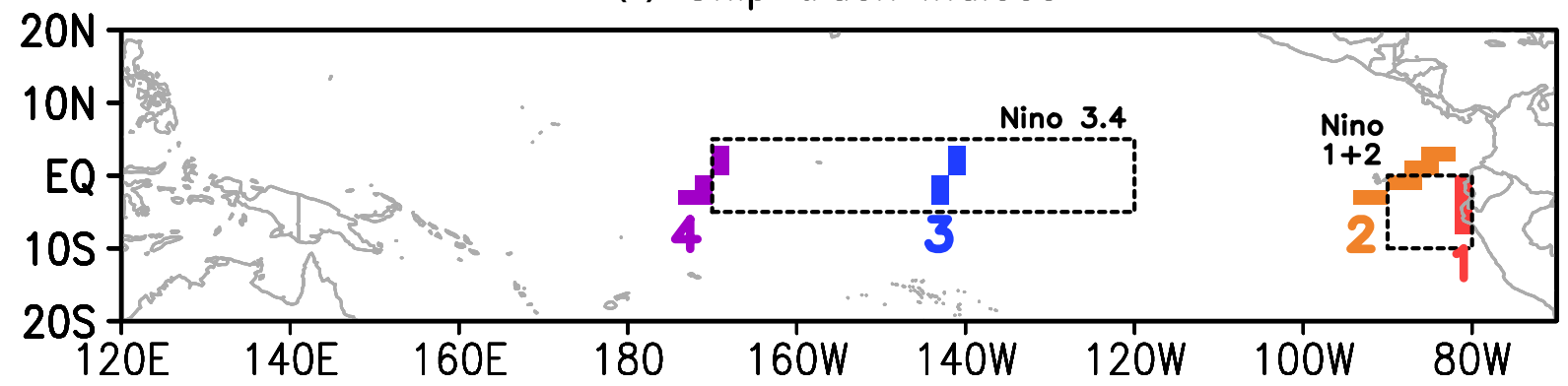

SST anom $\left({ }^{\circ} \mathrm{C}\right) \quad$ Zonal wind anom $(\mathrm{m} / \mathrm{s})$ Merid. wind anom $(\mathrm{m} / \mathrm{s})$

(b) Track 1

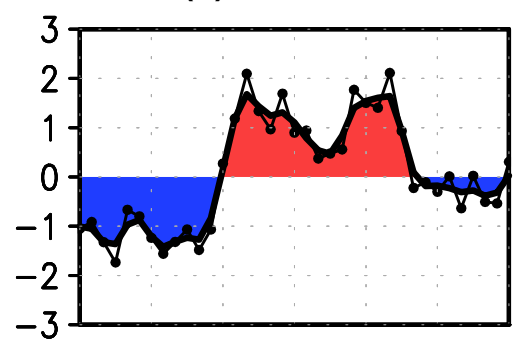

(c) Track 2

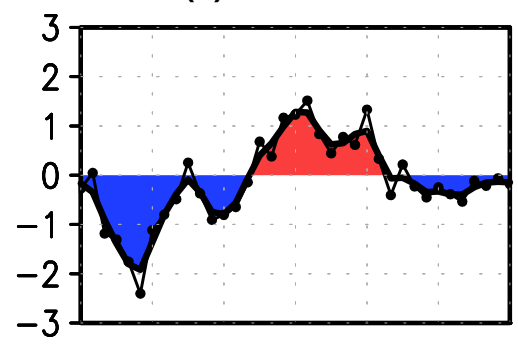

(d) Track 3

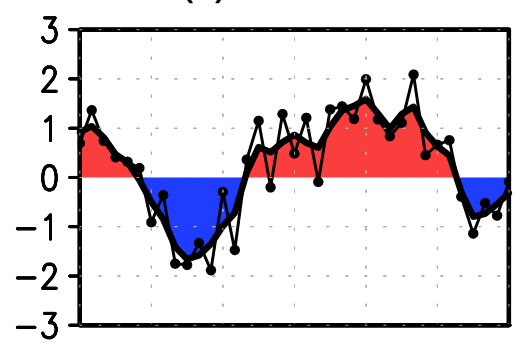

(e) Track 4

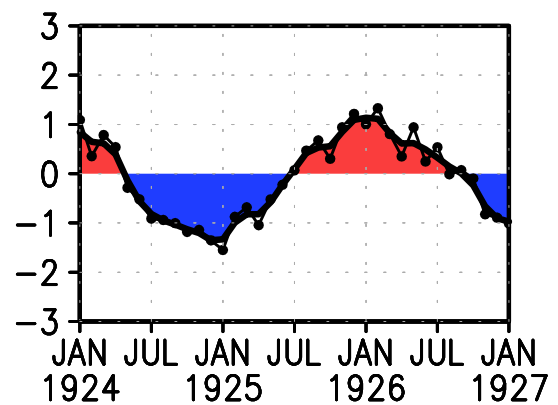

(f) Track 1

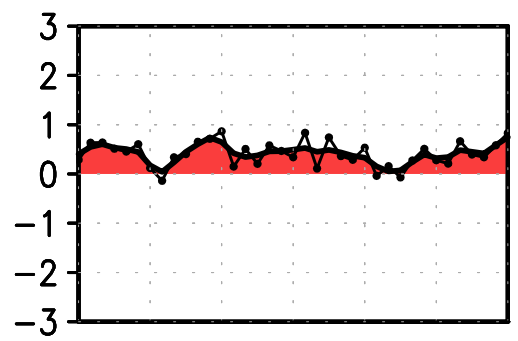

(g) Track 2

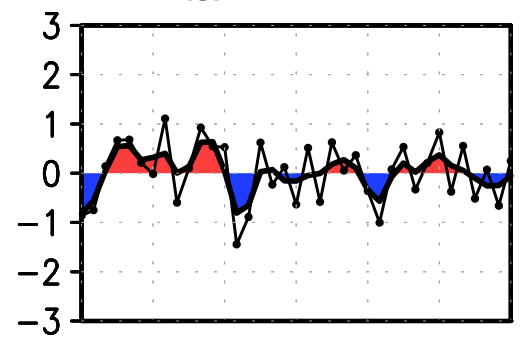

(h) Track 3

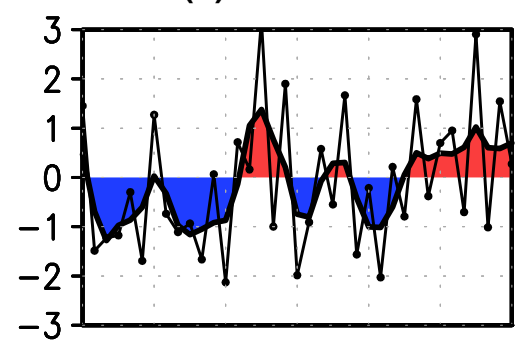

(i) Track 4

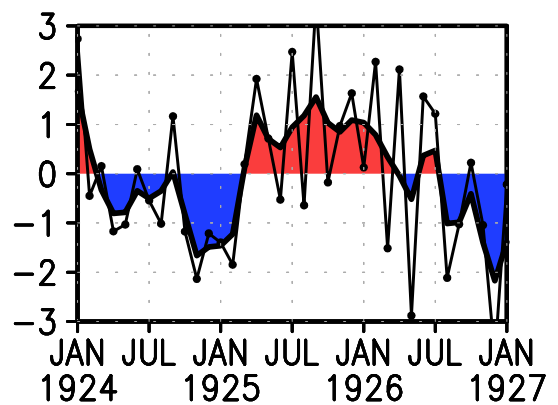

(j) Track 1

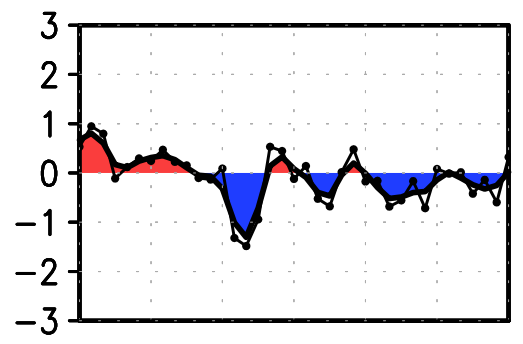

(k) Track 2

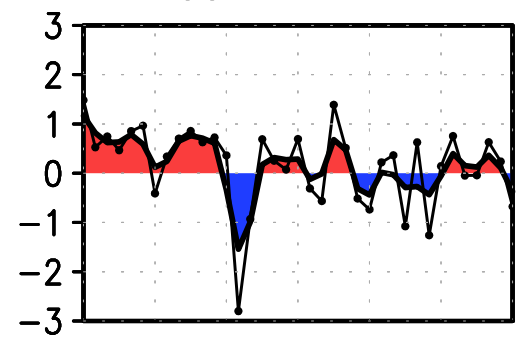

(I) Track 3

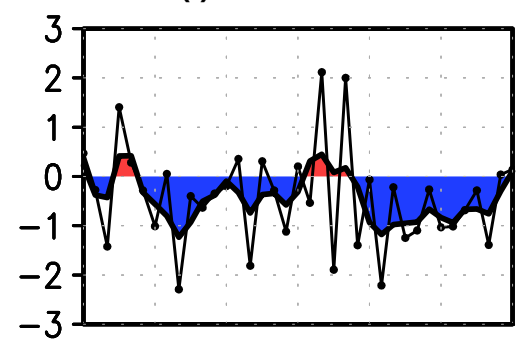

(m) Track 4

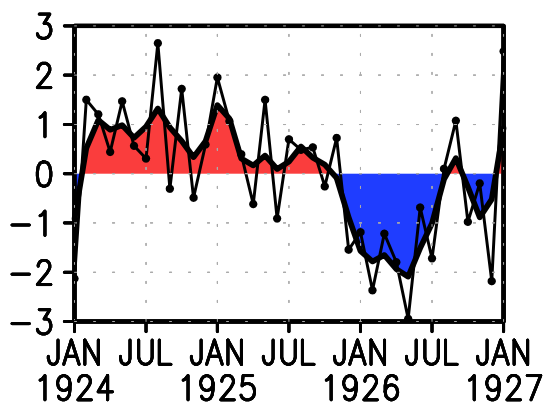


\Fig. 3 a Segments of the four ship tracks with the best data coverage in the central and eastern equatorial Pacific during the period 1920-39 (numbered 1-4 westward from the coast; standard Niño 1+2 and 3.4 regions indicated) and raw (thin) and 1-2-1-smoothed (colors, thick) monthly b-e SST $\left({ }^{\circ} \mathrm{C}\right)$ and $\mathbf{f}-\mathbf{i}$ zonal wind $(\mathrm{m} / \mathrm{s})$ anomalies along each of the ship tracks based on the gridded ICOADS data

(Dewitte and Takahashi 2016) and leading to the establishment of the warm ENSO phase.

In the next subsections we address specific mechanisms relevant to the development of this EN event.

\subsection{Lack of initial Kelvin wave forcing}

In the ENSO paradigm, the coastal warming is associated with downwelling equatorial Kelvin waves (e.g. Chiodi et al. 2014) that depress the thermocline and raise the sea level. However, in contrast to other EN events, the sea level data at Balboa, Panama, does not show positive anomalies in early 1925, and in fact they are negative in February (Fig. 4). Furthermore, we find that large sea level anomalies (e.g. $>10 \mathrm{~cm}$ ) in other EN events are associated with substantially weaker monthly SST anomalies than the one observed at Puerto Chicama in March 1925 (Fig. 4), with the exception of the peaks of the extreme 1982-83 and 1997-98 EN (Fig. 4d, f). Thus, a sea level anomaly associated with a downwelling Kelvin wave sufficiently strong to account for the observed warming in early 1925 could be expected to have been greater than $20 \mathrm{~cm}$.

On the other hand, the second warming peak in 1925 , starting in November, coincides with a $20 \mathrm{~cm}$ sea level anomaly, indicating that a downwelling equatorial Kelvin wave pulse was responsible (Fig. 4a). Downwelling Kelvin waves at this time are consistent with the westerly wind anomalies in the central Pacific (Fig. 3h-i), although this data cannot resolve specific westerly wind events.

Predominantly positive sea level anomalies were observed starting in May 1925 (Fig. 4a), after which the positive SST anomalies extended southward to $30^{\circ} \mathrm{S}$ (Fig. 5b). Particularly, the warming pulses in August-September 1925 and December 1925-February 1926 coincide with the positive sea level pulses around those times (Fig. 4a), providing further support to their interpretation as downwelling Kelvin wave pulses that were able to propagate the warming signal polewards into Chile, whereas the warming peak in March 1925 was restricted to north of $20^{\circ} \mathrm{S}$ (Fig. 5b).

Additional evidence of the absence of downwelling equatorial Kelvin wave forcing is provided by the hydrographic measurements from the Arcturus expedition east of the Galapagos (March 30-June 9, 1925) and the ship GB012817 along the coast of Colombia and Ecuador (April 17-19, 1925). The data from both indicate SST anomalously above $27^{\circ} \mathrm{C}$ near the equator, sharply decreasing to $19-20{ }^{\circ} \mathrm{C}$ at the $50 \mathrm{~m}$ depth (Fig. 6a, c). The equatorial anomalies calculated from the SODA climatology transition from generally positive at the surface to negative at $100 \mathrm{~m}$ (Fig. 6b, d, e). Conversely, strong downwelling Kelvin waves would result in a deep (>100 m) warm layer (Cucalon 1987; Garcés-Vargas et al. 2005; see profiles for 1983 and 1998 in Fig 7b, d, f, h).

The zonal wind showed weak positive anomalies $(<1$ $\mathrm{m} / \mathrm{s}$ ) in the FEP prior to the warming (Fig. 3f, g), which could have helped with the warming.

\subsection{Northerly winds and the ITCZ}

The most outstanding aspect of the atmospheric circulation in early 1925 was the extreme southward extension of the Panama wind jet, which climatologically reaches the equator in February and March (Fig. 8b, c) but in 1925 extended to $8-9^{\circ} \mathrm{S}$ and fanned out to the Galapagos (Fig. 8f, g). Similarly, the Papagayo jet further west extended almost to the equator near $95^{\circ} \mathrm{W}$ (Fig. 8f, g). The northerly anomalies were on the order of $2-3 \mathrm{~m} / \mathrm{s}$ (Figs. $3 \mathrm{j}, \mathrm{k}, 5 \mathrm{~b}, 9$ ), substantially stronger than in the EN composite of (Harrison and Larkin 1998) for February $\left(\sim 0.6 \mathrm{~m} / \mathrm{s}\right.$ around $3^{\circ} \mathrm{N}$ in their Fig. 6) and the RC82 composite for March-May (Fig. 19b in RC82). The onset of these northerly winds from January to February was abrupt, as was their retreat from March to April (Figs. 3j, k, 5a, b, 8a, b).

The enhancement of the northerly winds could have been the result of external atmospheric forcing. In the case of the gap jets through Central America, the forcing could be associated with the SLP difference between the Atlantic and the Pacific (Karnauskas et al. 2008). The ICOADS data shows positive SLP anomalies around Central America in both February and March 1925, with negative anomalies off Ecuador only clearly in March (Fig. 9a, b). However, although these (absolute) northerly winds were connected to the northeasterlies in the Caribbean, the northerly anomalies themselves were limited to the Pacific (Figs. 5b, 9). Furthermore, in situ observations of the integrated January-April northerly wind at Balboa and Cristobal, at both ends of the Panama Canal, indicate that 1925 did not have unusually high northerly winds (Schaeffer et al. 1958; Fig. S1). On the other hand, in February-March 1925, the Southern Oscillation was in a positive state (Fig. 1i), suggesting an enhanced South Pacific anticyclone, while the actual wind data does not show substantial subtropical wind anomalies (Fig. 5b), indicating that the northerly wind anomalies were not forced from the south Pacific. Therefore, atmospheric forcing from the Caribbean or the south Pacific does not appear to have had a key role in driving the northerly wind anomalies. 
Daily sea surface height anomaly $(\mathrm{cm})$ at Balboa $\left(9.0^{\circ} \mathrm{N}, 79.6^{\circ} \mathrm{W}\right)$

$\mathrm{cm}$ and monthly SST anomaly $\left({ }^{\circ} \mathrm{C}\right)$ at Puerto Chicama $\left(7.7^{\circ} \mathrm{S}, 79.4^{\circ} \mathrm{W}\right)$
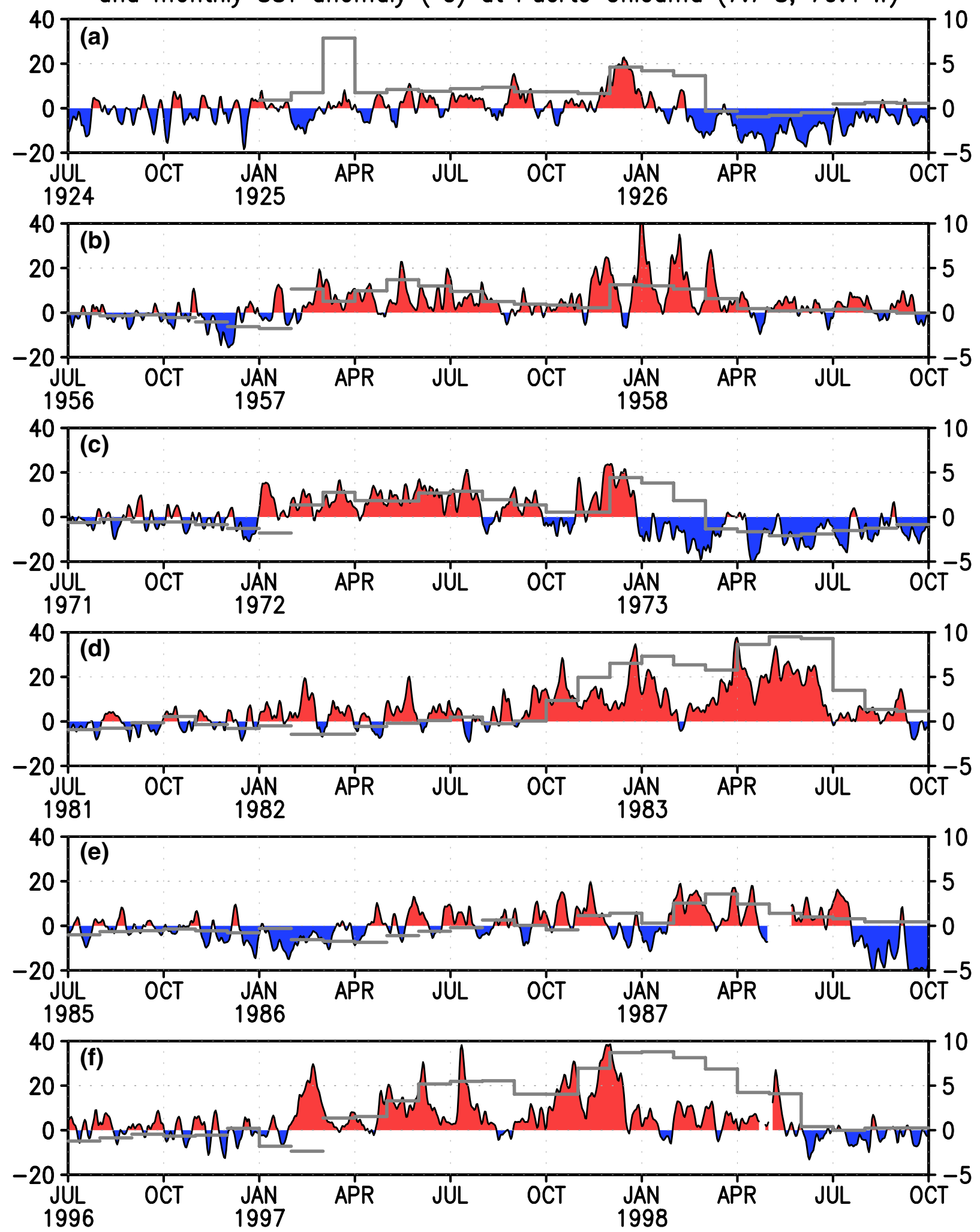

Fig. 4 Daily detrended sea surface height anomaly at Balboa (cm; colors) and monthly sea surface temperature anomaly $\left({ }^{\circ} \mathrm{C}\right.$; grey lines) for Puerto Chicama for selected El Niño events 
(a) Near-coastal ICOADS SST $\left({ }^{\circ} \mathrm{C}\right)$ and wind $(\mathrm{m} / \mathrm{s})$

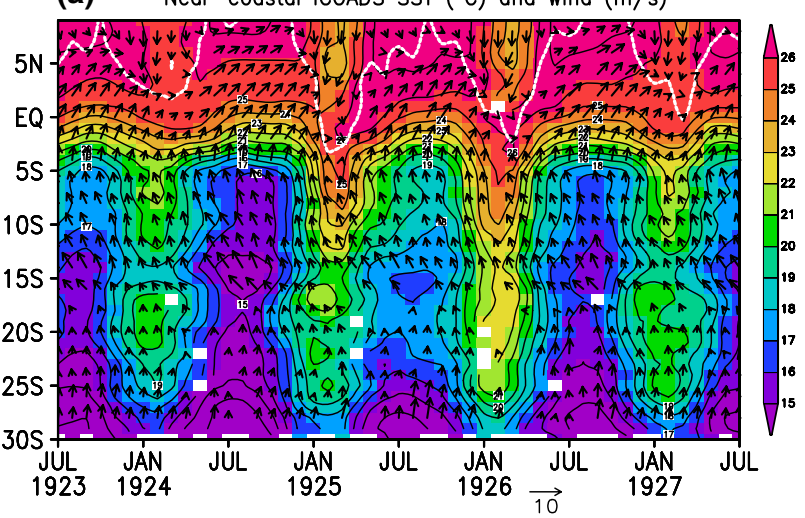

(b) Near-coastal ICOADS SST $\left({ }^{\circ} \mathrm{C}\right)$ and wind $(\mathrm{m} / \mathrm{s})$ anomaly

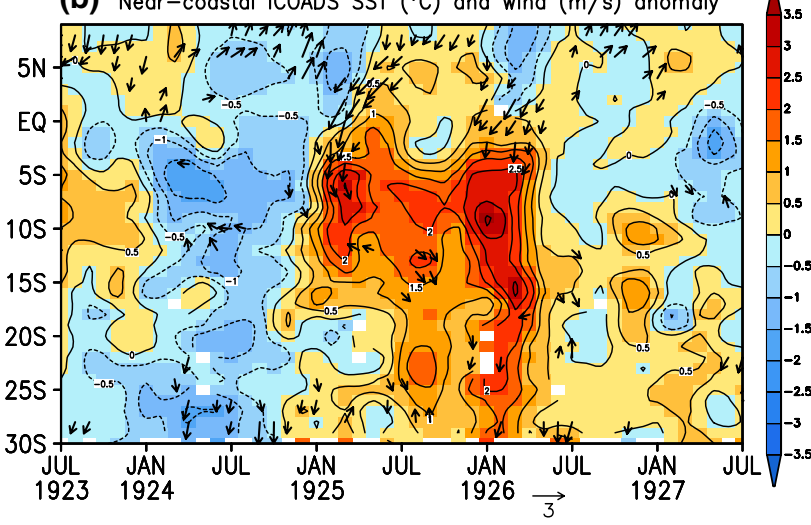

Fig. 5 a Monthly sea surface temperature (shading, ${ }^{\circ} \mathrm{C}$ ) and surface wind $(\mathrm{m} / \mathrm{s})$, and $\mathbf{b}$ the anomalies (with respect to 1920-39) from ICOADS along the near-coastal track. The zero meridional wind contour is solid white in $\mathbf{a}$

Another possibility is that local air-sea interaction amplified and maintained the northerly wind anomalies that could have been initiated by weak external atmospheric or oceanic forcing. Particularly, the meridional gradient in absolute SST near the coast was reversed, with the warmest/coolest waters found south/north of the equator (Figs. 5a, 8f, g). The SST anomalies presented a meridional dipole pattern with maxima at ${ }^{\circ} \mathrm{S}$ and $5^{\circ} \mathrm{N}$ and the northerly wind anomalies in-between (Fig. 5b). This anomalous SST gradient could directly reinforce the northerly winds via thermally-induced pressure gradients (Lindzen and Nigam 1987; Battisti et al. 1999) and, perhaps more importantly, the anomalously high SST south of the equator could strengthen the southern hemisphere ITCZ that climatologically is present in February-April around $5^{\circ} \mathrm{S}$ (Huaman and Takahashi 2016). The latter is suggested by the positive cloudiness anomaly in the ICOADS data around $2^{\circ} \mathrm{S}$ in February and, most notably, around $7^{\circ} \mathrm{S}$ in March (Fig. 9c, d). This enhancement of the SH ITCZ is consistent with the surface wind convergence off the coast of northern Peru (Fig. S2), as well as with the heavy rainfall observed in the otherwise arid northern-central coast of Peru (Sect. 3.4, "Appendix A"). Additionally, the barometric pressure measured at Chicama $\left(7.7^{\circ} \mathrm{S}\right)$ at 7 a.m. (to reduce the diurnal land heating effect; the $4 \mathrm{pm}$ data has similar variability but with lower values) indicates a large 9-10 hPa drop from around $1017 \mathrm{hPa}$ in the beginning of January to an average of $1008 \mathrm{hPa}$ in the second half of March (Fig. 10b), consistent with the establishment of the equatorial trough off the coast of Peru, with lower pressure than the March mean value of $1010 \mathrm{hPa}$ according to the TAO buoy at $5^{\circ} \mathrm{S}, 95^{\circ} \mathrm{W}$ for the years 2001-2003, probably an indication of the intensity of the anomalous SH ITCZ. On the other hand, the ICOADS data shows that the fanning of the Panama jet is associated with net surface wind divergence in the eastern Pacific north of the equator in February and March (but not in the Caribbean) instead of the climatological convergence (Fig. S2), consistent with the reduced cloudiness in the NH in March (Fig. 9d). The above suggests an anomalous local meridional overturning cell in the FEP in February-March 1925 with ascent/descent in the southern/northern hemisphere.

The existence of an approximate threshold SST for the activation of deep convection (Graham and Barnett 1987; Johnson and Xie 2010; Takahashi and Dewitte 2016; Jáuregui and Takahashi 2017) introduces a nonlinearity that can explain the abruptness of the onset of the $\mathrm{SH}$ ITCZ and northerly wind (Xie and Philander 1994, hereafter XP94; Wang and Wang 1999), which would take place more easily in the warm seasonal peak driven by insolation (Takahashi 2005). In this sense, the coastal EN could be described as an amplification of the seasonal cycle.

The wind speed anomalies associated with the northerly wind anomalies present a dipole pattern (not shown), with reduced/enhanced speed in the southern/northern hemisphere, contributing to reduced/enhanced surface evaporation and, therefore, enhanced/reduced SST. This positive wind speed-evaporation-SST (WES) feedback (XP94) probably was key in establishing this coastal EN event, which would imply that it would correspond to shallow solar warming. Another possible mechanism is meridional warm advection, which is discussed in the next subsection.

\subsection{The "Corriente del Niño"}

Meridional warm advection associated with an anomalously strong southward "Corriente del Niño" (El Niño Current; Carrillo 1893) was the first EN mechanism identified (Carranza 1891; Schott 1931). In 1891, in addition to warm water along the northern coast of Peru, carcasses of crocodiles and tree debris from north of $3^{\circ} \mathrm{S}$ were found at $8^{\circ} \mathrm{S}$ (Carranza 1891). In 1925 , the report at $4.6^{\circ} \mathrm{S}$ of a lizard not previously found in Peru but abundant off Ecuador at $3.2^{\circ} \mathrm{S}$ (Murphy 1926) and, in 1926 , of seeds at $4.6^{\circ} \mathrm{S}$ 
(a) Temperature at $0 \mathrm{~m}$

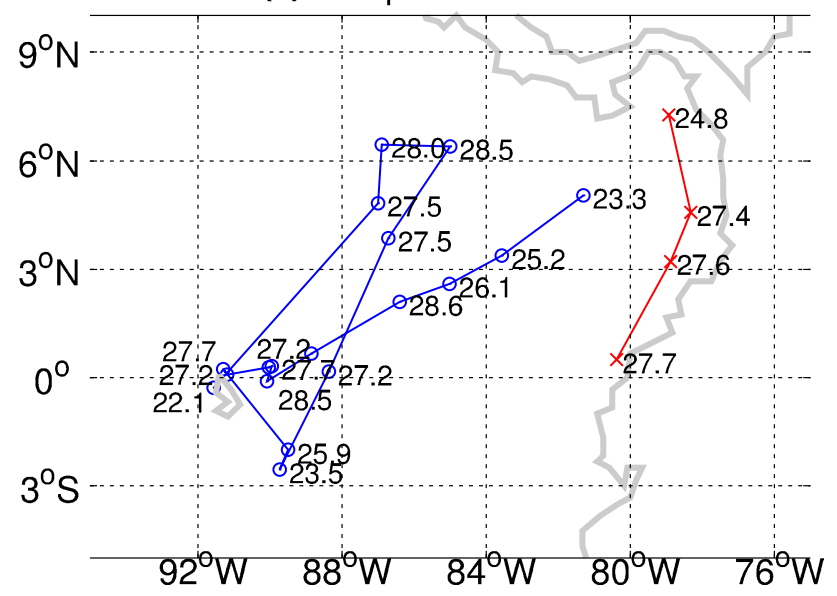

(c) Temperature at $50 \mathrm{~m}$

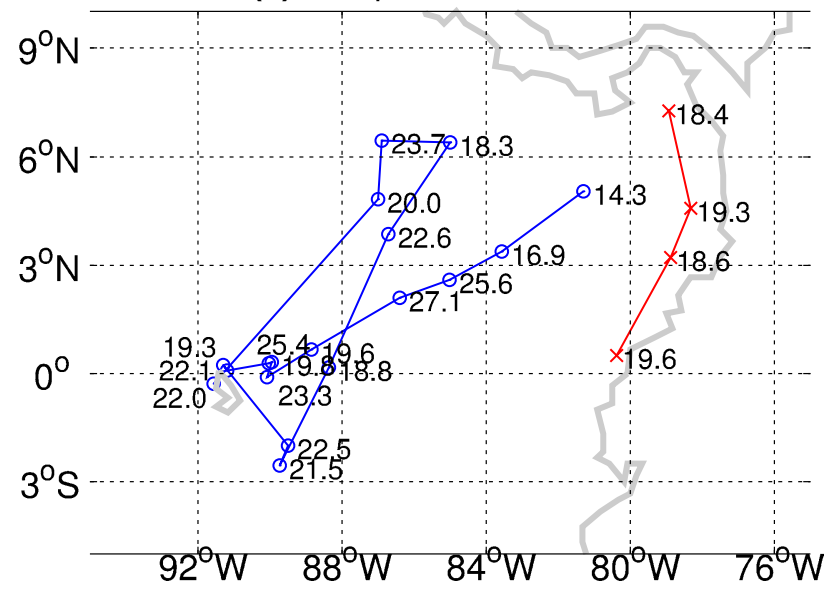

(e) Temperature at $100 \mathrm{~m}$

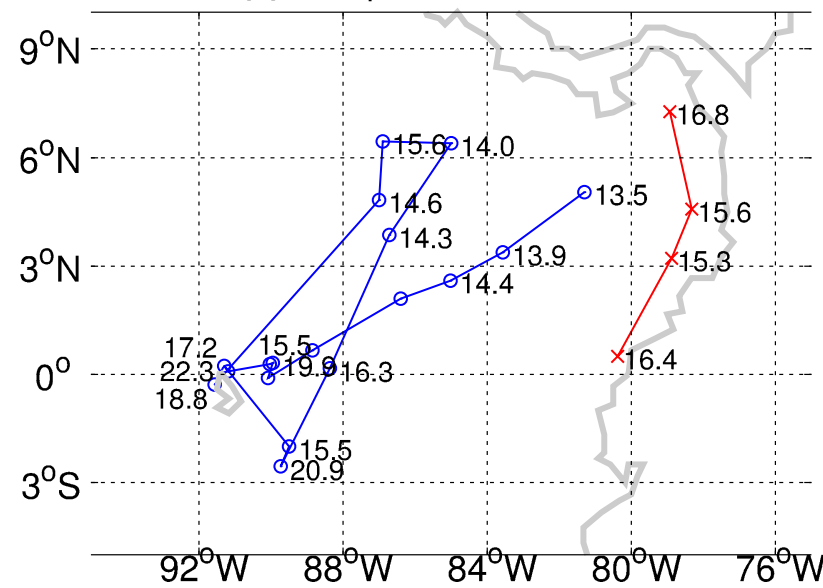

Fig. 6 a-c Temperature and d-f its anomalies at a,d $0 \mathrm{~m}$, b, e $50 \mathrm{~m}$, and c, f $100 \mathrm{~m}$ based on hydrographic measurements from the Arcturus (circles; March 30-June 9, 1925, starting on the east) and ship (b) Temperature anomaly at $0 \mathrm{~m}$

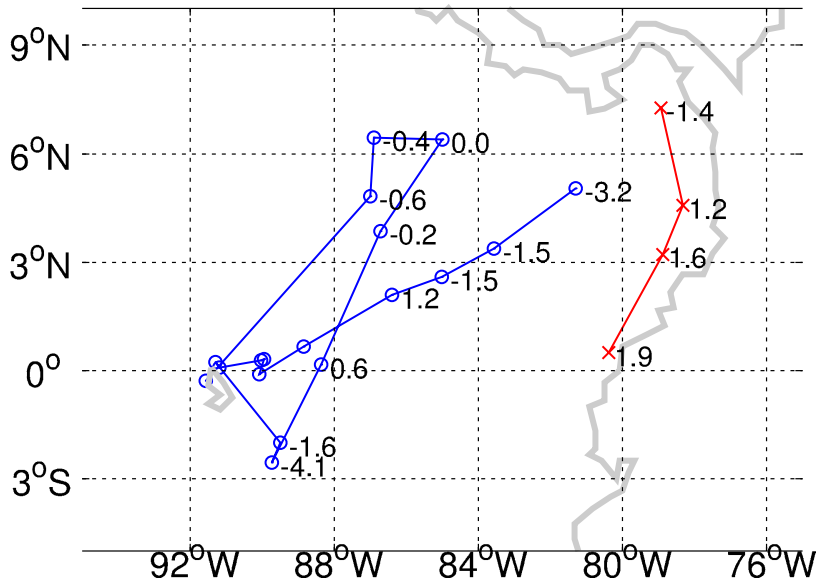

(d) Temperature anomaly at $50 \mathrm{~m}$

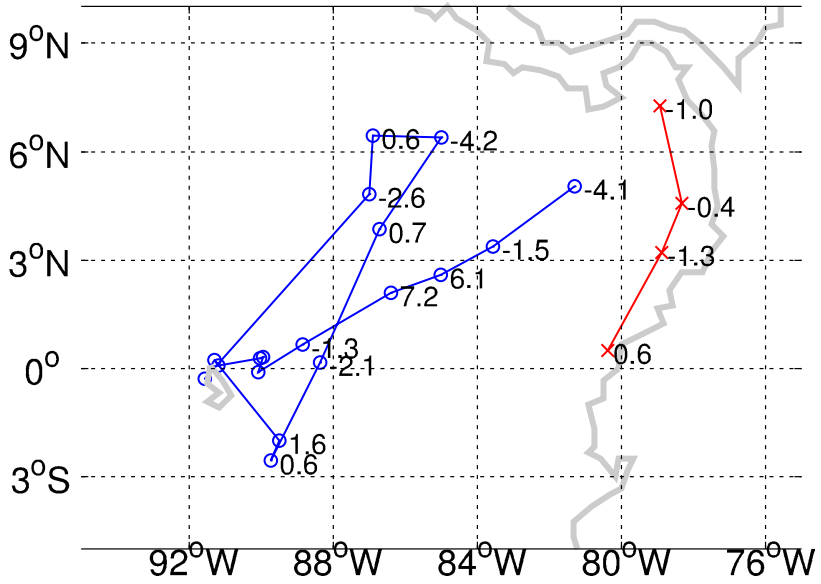

(f) Temperature anomaly at $100 \mathrm{~m}$

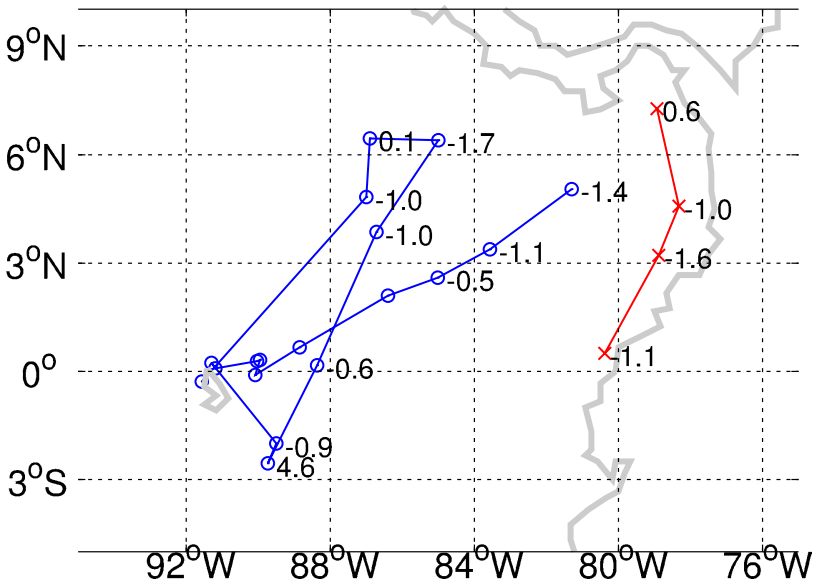

GB012817 (times symbols; April 17-19, 1925, starting on the south). The anomalies are calculated with respect to the SODA 1920-1939 climatology, except around the Galapagos were SODA is less reliable 
of mangroves that are found to the north of $3.6^{\circ} \mathrm{S}$ (Berry 1927), are also indications of southward advection.

From the end of January through February 1925, ship drift data along the coastal track indicate southward flow north of the equator, with a speed on the order of 30-50 $\mathrm{cm} / \mathrm{s}$ (Zorell 1929). Murphy (1926) also reported coastal measurements of southward flow of around $50 \mathrm{~cm} / \mathrm{s}$ further south $\left(5\right.$ and $\left.2^{\circ} S\right)$ within the same period. Schott (1931) discussed the southward progression of warm SST fronts in early 1925 using cruise data and coastal stations, with the warmest front reaching Puerto Chicama in February 27, Callao in March 12 (Fig. 10a) and as far south as Pisco in March $16\left(14^{\circ} \mathrm{S}\right)$, from which he inferred a southward propagation speed of $40-50 \mathrm{~cm} / \mathrm{s}$, although onshore advection, as observed in the 1982-83 and 1997-98 events (Morón 2011), is another possibility.

Having discarded the possibility of strong downwelling Kelvin waves (Sect. 3.1), the strong northerly winds are the most likely forcing of the warm countercurrent [e.g. Philander and Pacanowski (1981)]. We can produce a rough estimate of the wind-driven surface current $\mathbf{u}$ based on the wind observations by neglecting the Coriolis force near the equator and considering the frictional balance $r_{s} \mathbf{u}=\tau / \rho H$, where $r_{s} \approx(2 \text { days })^{-1}$ is a frictional dissipation rate (Zebiak and Cane 1987; Dewitte 2000), $\rho \approx 10^{3} \mathrm{~kg} / \mathrm{m}^{3}$ is the water density, $\tau=\rho_{a} C_{D}\left|\mathbf{u}_{a}\right| \mathbf{u}_{a}$ is the surface wind stress with $\left|u_{a}\right| u_{a}$ indicating the surface wind pseudo-stress, $\rho_{a}=1.2 \mathrm{~kg} \mathrm{~m}^{-3}$ the air density and $C_{D}=2 \times 10^{-3}$ the drag coefficient (Perigaud et al. 2000). Based on the individual ICOADS observations, the near-coastal pseudostress had a mean northerly component of $15.5 \pm 4.7 \mathrm{~m}^{2} / \mathrm{s}^{2}$ around the equator $\left(1^{\circ} \mathrm{S}-1^{\circ} \mathrm{N}\right)$ in February-March 1925. Assuming an Ekman layer depth of $H=30 \mathrm{~m}$ (Oerder et al. 2015), we calculate the equatorial southward current speeds as $18 \pm 5 \mathrm{~cm} / \mathrm{s}$. This is a lower bound, since the high SST implies reduced atmospheric stability, i.e. larger $C_{D}$ and wind stress, while the ocean stratification associated with the shallow fresh warm surface (Fig. 7h, i) suggests a shallower $H$. Additionally, changing observational practices (i.e. Beaufort scale vs anemometers) and anemometer heights due to increasing ship sizes (Cardone et al. 1990) introduces further underestimation of the wind stress. Thus, the estimated wind-driven current speed provides a lower bound that is consistent with the other observational estimates for the "Corriente del Niño" speed.

Additionally, the northerly wind anomaly enhanced the upwelling in the Panama bight (Alory et al. 2012), with cold water extending almost to the surface, except for a very shallow warm layer (Fig. 7b), and salinities typical of the $100 \mathrm{~m}$ depth (Fig. 7c). This is similar to what was observed in 1891 (Schott 1931) but contrasts sharply with the extreme EN conditions in April 1983 and 1998, which featured a deep fresh warm layer of around $80 \mathrm{~m}$ depth (Fig. 7a-g).

\subsection{Local and remote sea surface temperature control on eastern Pacific precipitation}

The dependence of coastal precipitation of SST approximately follows the threshold model of XP94 (see Sect. 3.2), but with a threshold SST of around $26^{\circ} \mathrm{C}$ (Woodman 1999; Takahashi 2004; Ramos 2014). This model provides an adequate qualitative explanation for the temporal evolution of the periods of strong rainfall and river discharge events at different latitudes along the Peruvian coast (Fig. 10c-g), as they approximately coincide with the periods in which the local near-coastal SST [based on the ship analysis of Schott (1931)] was greater than $26{ }^{\circ} \mathrm{C}$ (indicated with lines in Fig. 10c-g). These conditions were progressively established from north to south and ended in the reverse order. The details of the severe impacts at various sites along western Peru and Ecuador associated with heavy rainfall and flooding in 1925, which can provide important guidance for paleoclimatic and historical EN reconstructions as well as for risk management, are presented in Appendix A.

On the other hand, the cool central Pacific SST is also known to enhance the precipitation in the mid and upper basins along the western Andes of Peru (Lavado-Casimiro and Espinoza 2014). This is explained by the connection of SST in the western Pacific warm pool connects to the whole tropical free troposphere via deep convection, cooling it during basin-scale La Niña conditions (Yulaeva and Wallace 1994; Chiang and Sobel 2002), which reduces the tropospheric stability and facilitates convection (Vecchi and Soden 2007; Jáuregui and Takahashi 2017), while also producing easterly near-equatorial upper-air wind anomalies over South America that are also favorable for convection (Kousky and Kayano 1994; Vuille et al. 2000).

The role of local and remote forcing is verified for the Piura river by the relatively high positive correlation between its annual mean discharge (reconstructed as described in Appendix B) with February-March mean SST in the FEP $(r=0.69$ in the Niño $1+2$ region; Fig. 11a, b), and negative values in the western-central equatorial Pacific $\left(r=-0.17\right.$ in the region we denote as $T_{w}$ $\left(155^{\circ} \mathrm{E}-175^{\circ} \mathrm{W}, 5^{\circ} \mathrm{S}-5^{\circ} \mathrm{N}\right.$; Fig. $\left.11 \mathrm{a}, \mathrm{c}\right)$. On the other hand, we see in the scatter plots that the two relationships are not linear and that the correlation with Niño $1+2$ is strongly dominated by the 1982-83 and 1997-98 events, which are outliers in the correlation with $T_{w}$ (Fig. 11b, c). However, if we simply subtract $T_{w}$ from Niño $1+2$, providing a rough index of tropospheric stability in the eastern Pacific, we not only find an enhanced correlation $(r=0.72)$, but generally a more monotonic nonlinear relationship (Fig. 11d). The high SST in $T_{w}$ during the warm ENSO phases in 1926 and 2016 explain why the river discharge was not as high in those years despite the high Niño 1+2 SST, whereas 1925 and 2008 had high discharges due to the low SST in 
(a) Stations in Apr 1925

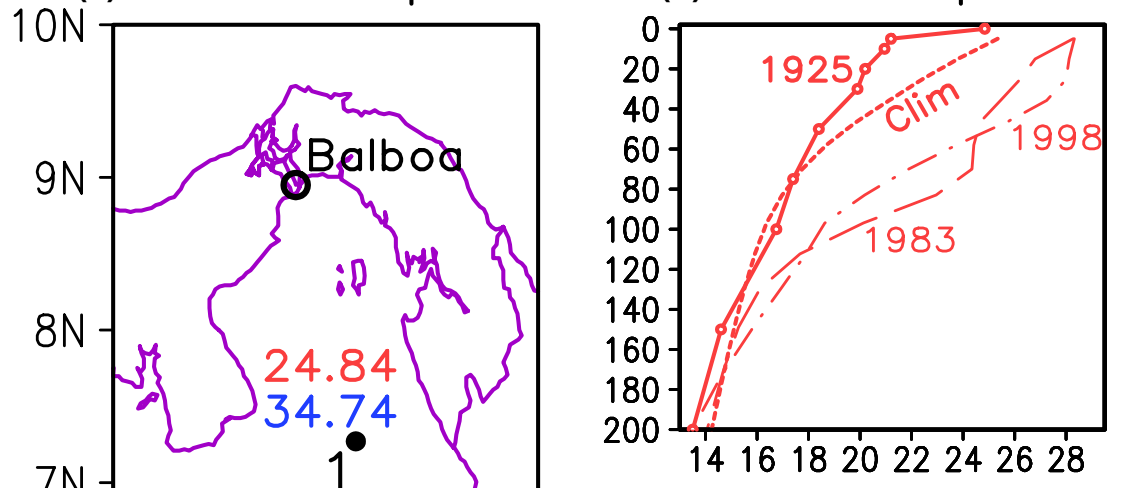

(d) Stn 2: Temperature

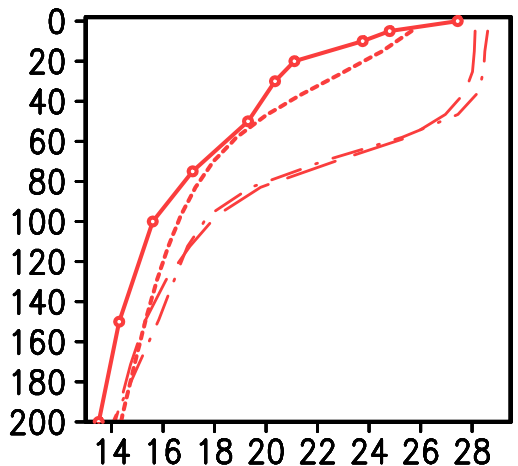

(f) Stn 3: Temperature

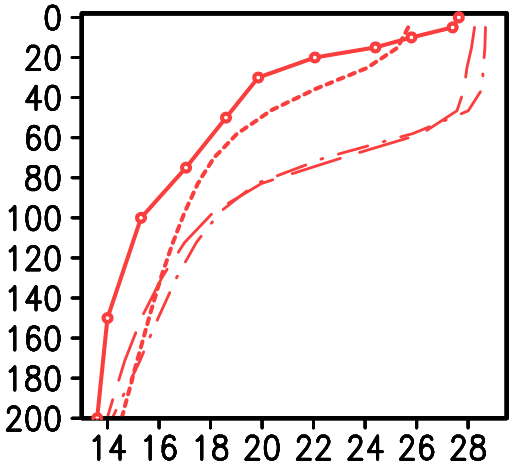

(h) Stn 4: Temperature

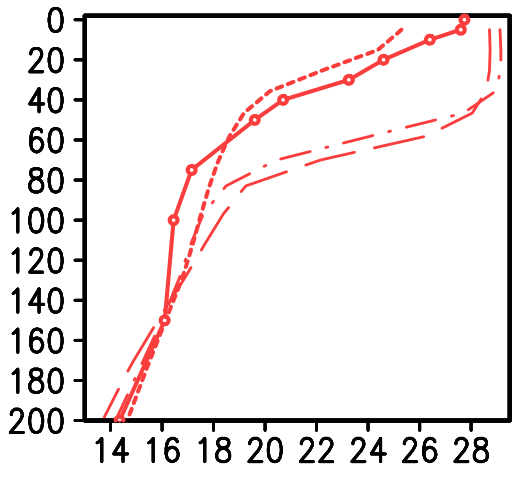

${ }^{\circ} \mathrm{C}$ (c) Stn 1: Salinity

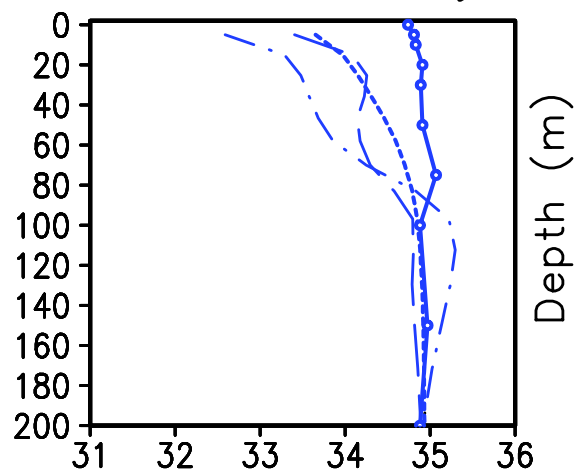

(e) Stn 2: Salinity

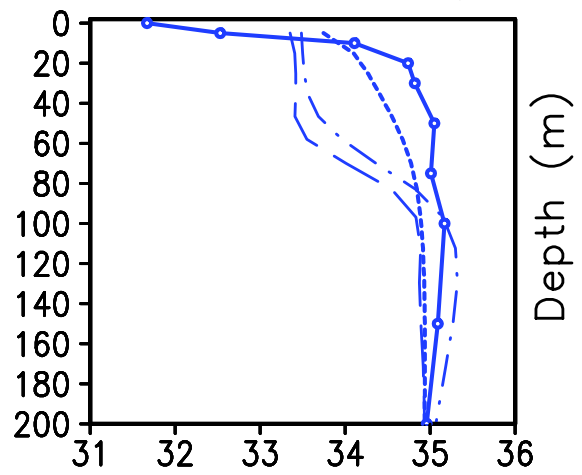

(g) Stn 3: Salinity

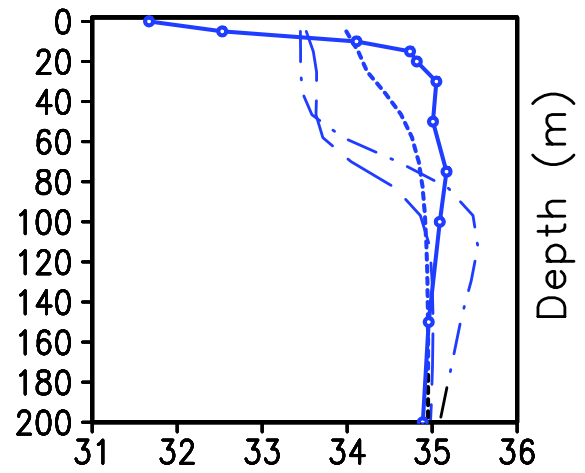

(i) Stn 4: Salinity

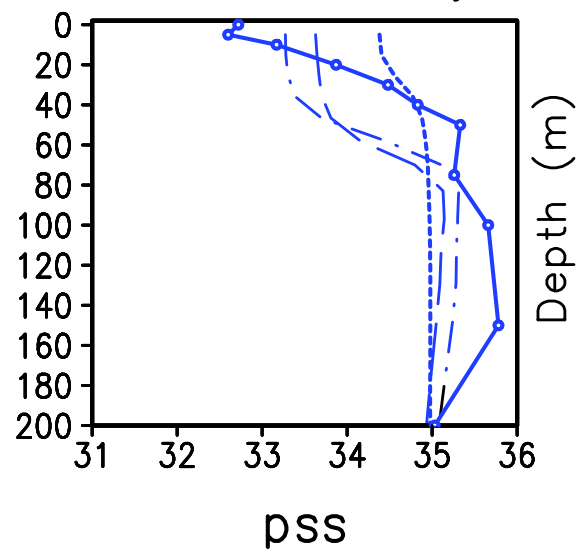


4Fig. 7 a Location of four oceanographic stations from the GB012817 ship (labeled 1-4) in April 17-19, 1925 (starting with station 4$)$. The surface temperature $\left({ }^{\circ} \mathrm{C}\right)$ and salinity (pps) are indicated in red and blue, respectively. Observed profiles of $\mathbf{b}, \mathbf{d}, \mathbf{f}$, h) temperature and $\mathbf{c}, \mathbf{e}, \mathbf{g}, \mathbf{i})$ salinity (solid) are shown for stations $\mathbf{b}, \mathbf{c} 1, \mathbf{d}, \mathbf{e} 2, \mathbf{f}, \mathbf{g} 3$, and $\mathbf{h}, \mathbf{i} 4$. Also included are the climatology for April (1920-39, thick short dashed), and the data for April 1983 (long dashed) and 1998 (dot-dashed) for the nearest grid cell from SODA 2.2.4

$T_{w}$ and high Niño 1+2 SST. The 2008 case is interesting because it was primarily regarded as a basin-scale La Niña (cool ENSO) event (Bendix et al 2011). The nonlinearity of the relation between Niño $1+2-T_{w}$ and the discharge, with a sharp increase in slope above $-1.5{ }^{\circ} \mathrm{C}$, can also explain why the strong EN (warm ENSO) failed to produce rainfall in northern Peru as strong as in 1983 or 1998 despite having similar Niño 3.4 SST (L'Heureux et al. 2016).

We hypothesize that a similar process reduced the stability of the seasonal southern hemisphere ITCZ in 1925, which in the context of the XP94 model could have been through a combination of lowering of the threshold SST and/or enhancing the rate of the precipitation increase with SST due to basin-scale La Niña (cool ENSO) conditions, which cools the free troposphere and produces easterly upper-air anomalies (both of which are indicated by the 20CRv2 in 1925, not shown). In this view, this type of coastal EN would be the result of the interannual destabilization of the seasonal cycle in the FEP by the cool ENSO phase. (a) Jan (clim)
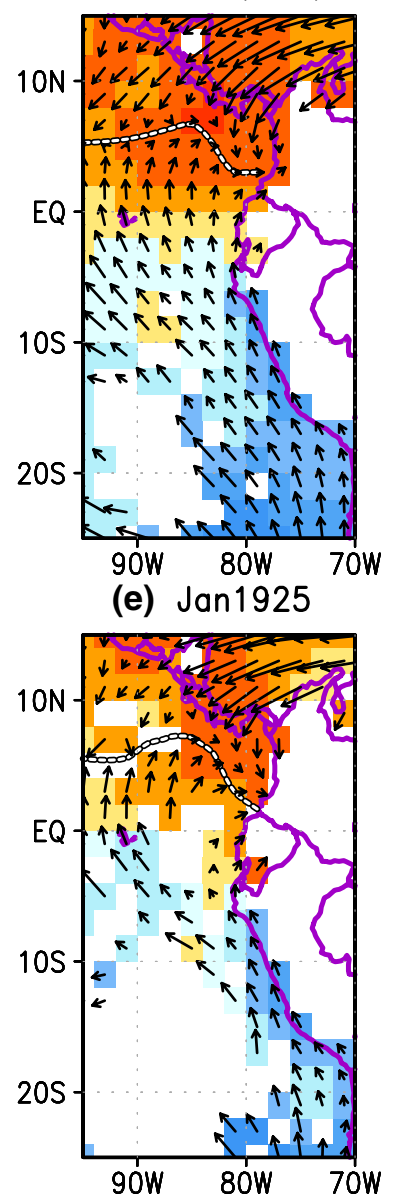

(b) Feb (clim)

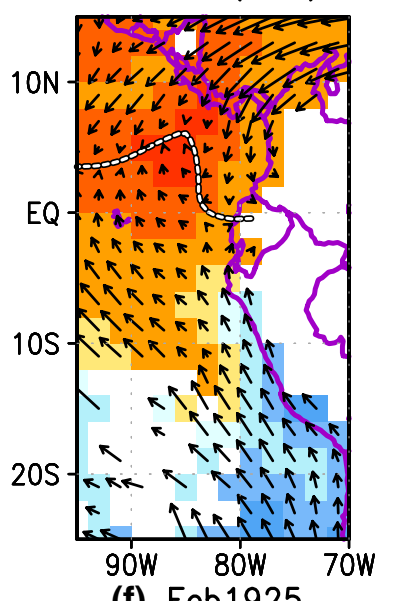

(f) Feb1925

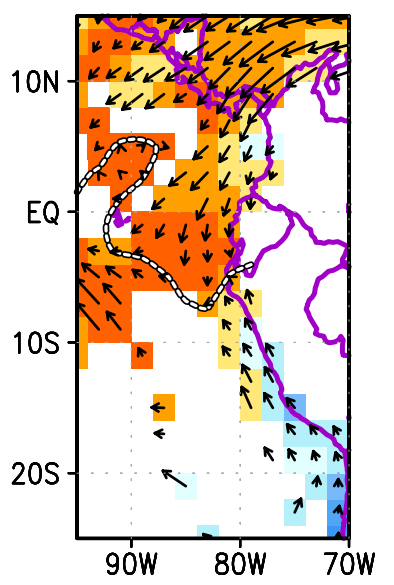

(c) Mar (clim)

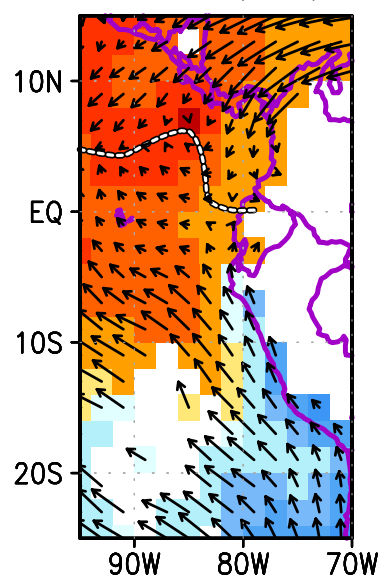

(g) Mar1925

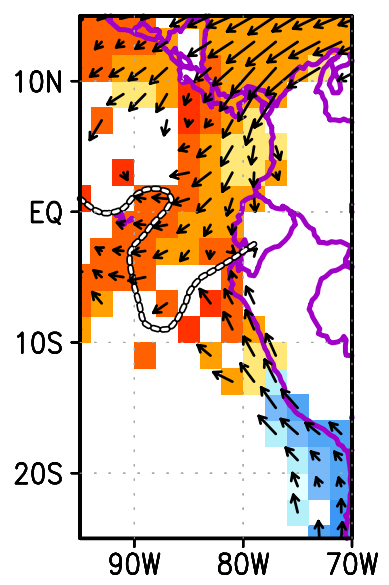

(d) Apr (clim)

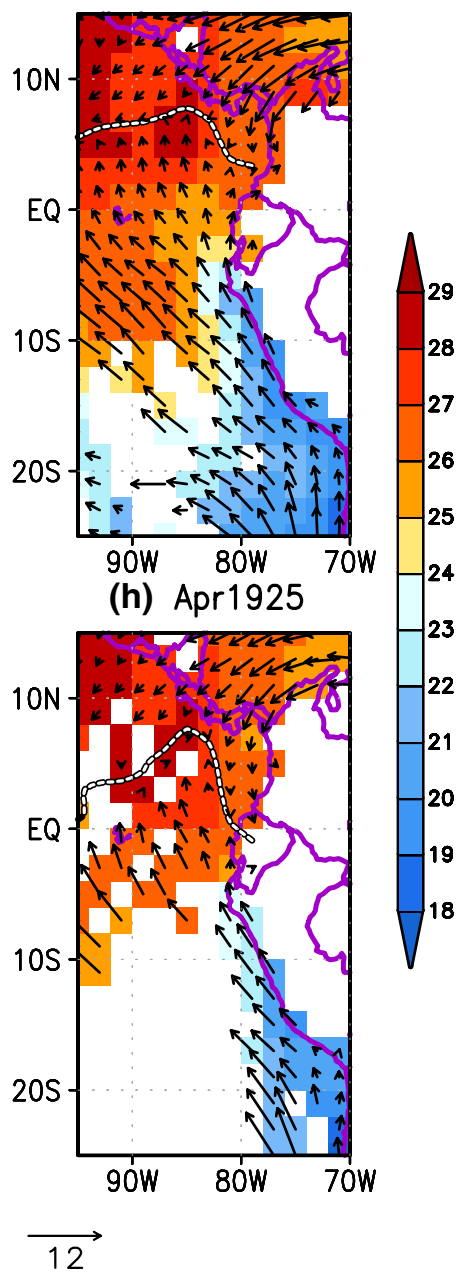

Fig. 8 ICOADS sea surface temperature (shading, $\left.{ }^{\circ} \mathrm{C}\right)$ and surface winds (m/s) for January through April for the 1920-39 climatology (top row), and year 1925 (bottom row). The $26^{\circ} \mathrm{C}$ isotherm (solid and light purple) and the zero meridional wind contour (dashed) are included 
$\begin{array}{ll}\text { (a) SLP and wind (Feb 1925) } & \text { (b) SLP and wind (Mar 1925) }\end{array}$
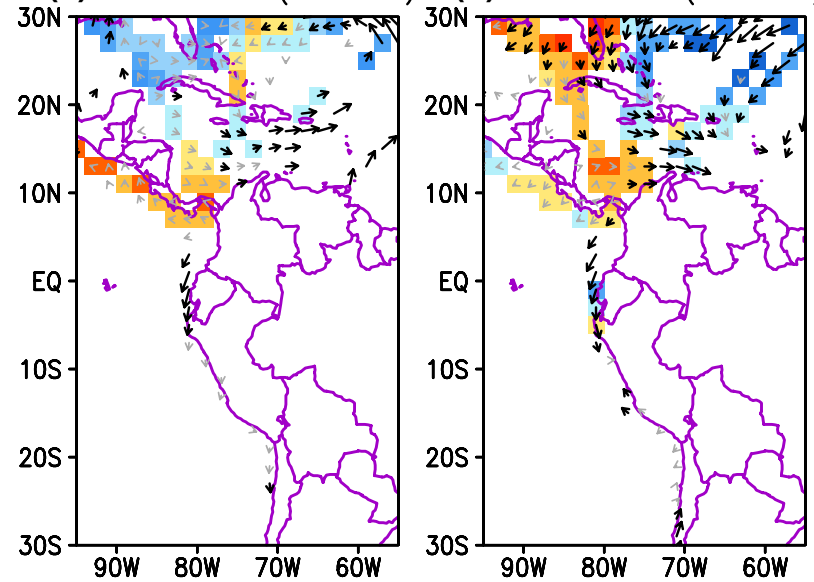

(c) $\mathrm{CC}$ and wind (Feb 1925)

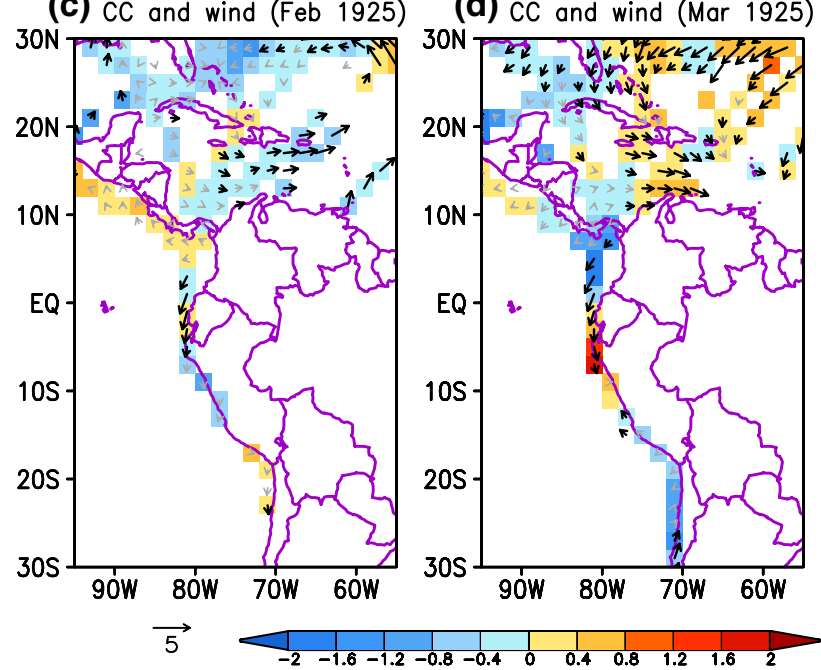

Fig. 9 Monthly anomalies of surface wind (m/s; vectors) overlayed on a, b cloud cover (octas; shading) and c, d) sea level pressure (hPa; shading anomalies from ICOADS for $\mathbf{a}, \mathbf{c}$ February and $\mathbf{b}$, d March 1925. Only grid cells with at least 15 observations are shown (slight spatial smoothing). Anomaly vectors with magnitude larger than 1 $\mathrm{m} / \mathrm{s}$ are darker

\section{Discussion}

The ENSO paradigm is based on the interaction between equatorial ocean dynamics and zonal winds through SST. Historically, however, the association of northerly winds in the FEP with EN had been noted by Eguiguren (1894) and Murphy (1926), while Schott (1931) went further to propose that these winds were the forcing of the coastal EN. This hypothesis subsequently was countered by the finding that the coastal winds tend to strengthen during EN (Wyrtki 1975; Enfield 1981; Rasmusson and Carpenter 1982) and Wooster (1980) argued that Schott failed by "underestimating the magnitude of the time and space scales involved". But none of this later studies explicitly analyzed the 1925 and their failure was in implicitly assuming that the same mechanisms act in the same way in every event, despite Wyrtki's (1975) conclusion that "El Niño certainly does not have only a single cause".

Nevertheless, the RC82 and the Harrison and Larkin (1998) EN composites do show northerly wind anomalies during the coastal warming phase, but weak compared to 1925. The seasonality of these anomalies appears to be critical for the strong feedback between SST, the ITCZ and the northerly wind, as the SST and the ITCZ off Peru peak climatologically around March (Takahashi 2005; Huaman and Takahashi 2016). We argue that this feedback was made more effective in 1925 by the dominant cold conditions in the rest of the equatorial Pacific, which promoted convection in the FEP by the destabilition of the troposphere and with moist easterly advection from the Amazon. However, strong northerly anomalies were also observed in early 1926, around the peak of the warm ENSO phase (Fig. 12a). This suggests that perhaps longer-term changes, like a lower convective threshold for convection (Johnson and Xie 2010), could have made this mechanism more effective in the past. In fact, the latitude of the trade-wind confluence in these two years has been the lowest in the 1920-2012 period, including the extreme 1982-83 and 1997-98 events and there is a slight (but not significant) northward trend in this latitude, perhaps a response to the stabilization associated with the long-term tropical tropospheric warming (Johnson and Xie 2010; Jáuregui and Takahashi 2017). Consistent with this, the low tropospheric stability estimated as the difference between the $700 \mathrm{hPa}$ potential temperature from the 20CRv2 and SST in the Niño 1+2 region (not shown) also has a small albeit not significant positive trend. On the other hand, the SST difference between the Niño $1+2$ and the $T_{w}$ region, a stability proxy for the FEP (see Sect. 3.4) does not show a clear trend (Fig. 12b), although uncertainty in SST reconstructions is an issue for trends in the zonal SST gradient in the tropical Pacific (Deser et al. 2010). On the other hand, many climate future climate change projections with global climate models indicate a joint trend in increasing rainfall and northerly wind anomalies off northern Peru similar to the proposed for the $1925 \mathrm{EN}$ (Belmadani et al. 2014), but the models in general continue to have strong biases in this region, particularly the double ITCZ syndrome (Zhang et al. 2015).

If we focus on the extreme EN impacts in western tropical South America (e.g. Figs. 1a-f, 12c), both the largescale version (1982-83, 1997-98) or this coastal version have similar signatures. So not only is the record too sparse to identify trends that differentiate between the two types, but the two trends would be responding to different processes. This is important for long-term reconstructions of ENSO diversity. The interpretation of paleoclimatic and historical records of extreme EN impacts in the FEP (high 
Fig. 10 Daily series for January-April 1925: a sea surface temperature in Puerto Chicama and Callao $\left({ }^{\circ} \mathrm{C}\right.$; open circles and dots, respectively), b barometric pressure in Chicama (hPa; 1-2-1 smoothed), c precipitation in Zorritos (mm; Petersen 1935), d Piura river discharge $\left(\mathrm{m}^{3} / \mathrm{s}\right.$; thick circles are discharge reconstructed from water height; small and large black triangles indicate days with moderate and heavy rainfall, respectively, in the city of Piura, Table S2), e Virú (black) and Chicama (grey) river discharge $\left(\mathrm{m}^{3} / \mathrm{s}\right.$; Zegarra, 1926), $\mathbf{f}$ precipitation in Trujillo (mm; *the accumulated value for March 7-9 was reported on March 9), and $\mathbf{g}$ precipitation in Lima (mm; El Comercio, 1925). Data was digitized from Murphy (1926) unless explicitly indicated. Days with missing data are shaded (except for the gaps in the Chicama discharge), and, in the case of precipitation, they are assigned a value of zero (following Petersen 1935). In b-f, thick black lines indicate when the near-coastal SST analysis of Schott (1931) exceeded $26^{\circ} \mathrm{C}$ at the corresponding locations (for Zorritos, dashed indicates extrapolation) (a) SST $\left({ }^{\circ} \mathrm{C}\right)$ in Chicama $\left(7.7^{\circ} \mathrm{S}\right.$, circles) and Callao $\left(12^{\circ} \mathrm{S}\right.$, dots)

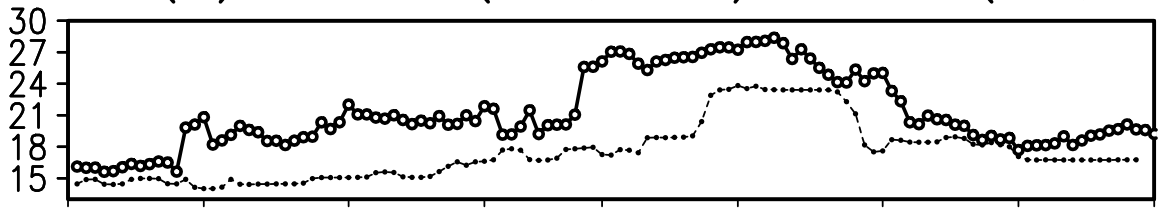

(b) Barometric pressure $(\mathrm{hPa})$ at Chicama $\left(7.7^{\circ} \mathrm{S}\right)$

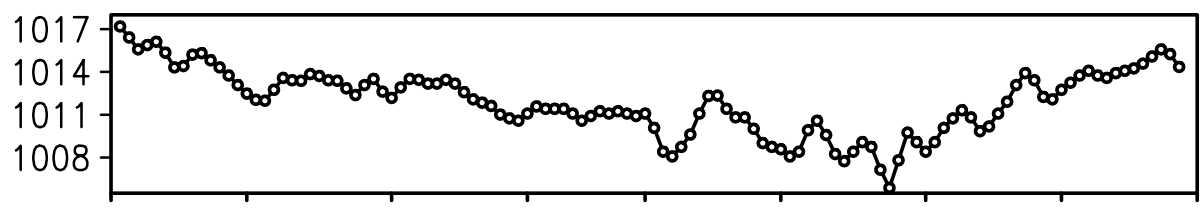

(c) Precipitation in Zorritos $\left(3.7^{\circ} \mathrm{S}, \mathrm{mm}\right)$

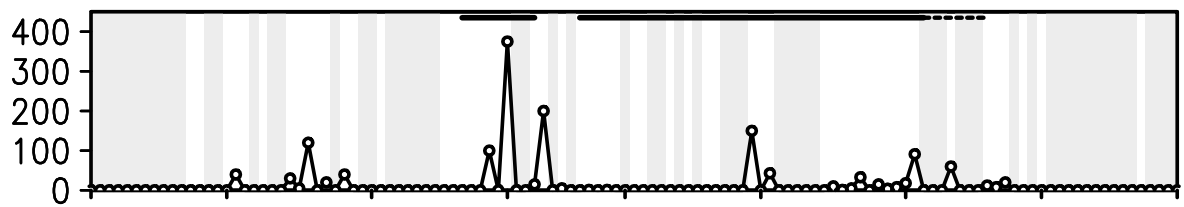

(d) Piura river discharge $\left(5.2^{\circ} \mathrm{S}, \mathrm{m}^{3} / \mathrm{s}\right)$ and rainy days (triangles)

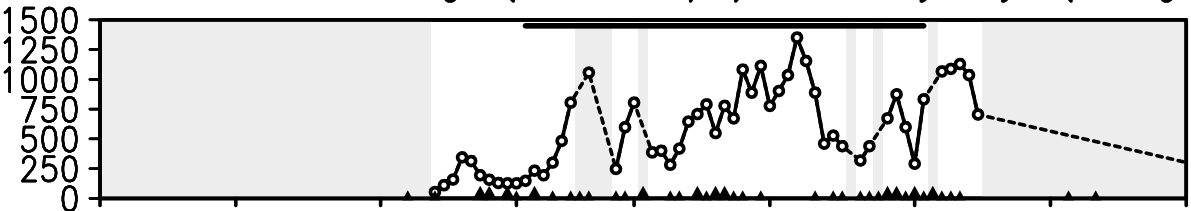

(e) Viru $\left(8.4^{\circ} \mathrm{S}\right.$, black) and Chicama $\left(7.7^{\circ} \mathrm{S}\right.$, grey) discharge $\left(\mathrm{m}^{3} / \mathrm{s}\right)$ 1000
$800-1$
$600-1$
$400-1$
$200-1$

(f) Precipitation in Hacienda Herederos, Trujillo $\left(8.1^{\circ} \mathrm{S}, \mathrm{mm}\right.$ )

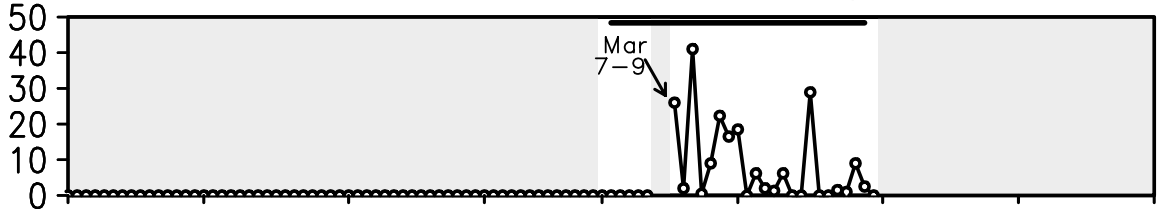

(g) Precipitation in Lima $\left(12^{\circ} \mathrm{S}, \mathrm{mm}\right)$

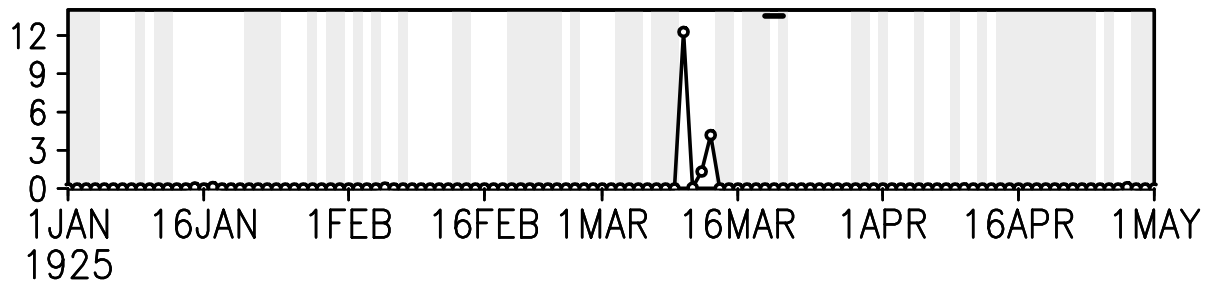

temperatures, flooding, impacts on marine ecosystems) would need to carefully consider these two types, ideally contrasting with proxies from other regions that help with the discrimination of the two.

\section{Conclusions}

In this study we revisited the very strong $1925 \mathrm{El} \mathrm{Niño}$ (EN), the third strongest, after 1982-83 and 1997-98, in terms of its impacts on the far-eastern Pacific (FEP) associated with heavy rainfall on the coasts of southern Ecuador 
(a) Corr(Annual discharge, Feb-Mar SST) (1925-2016)

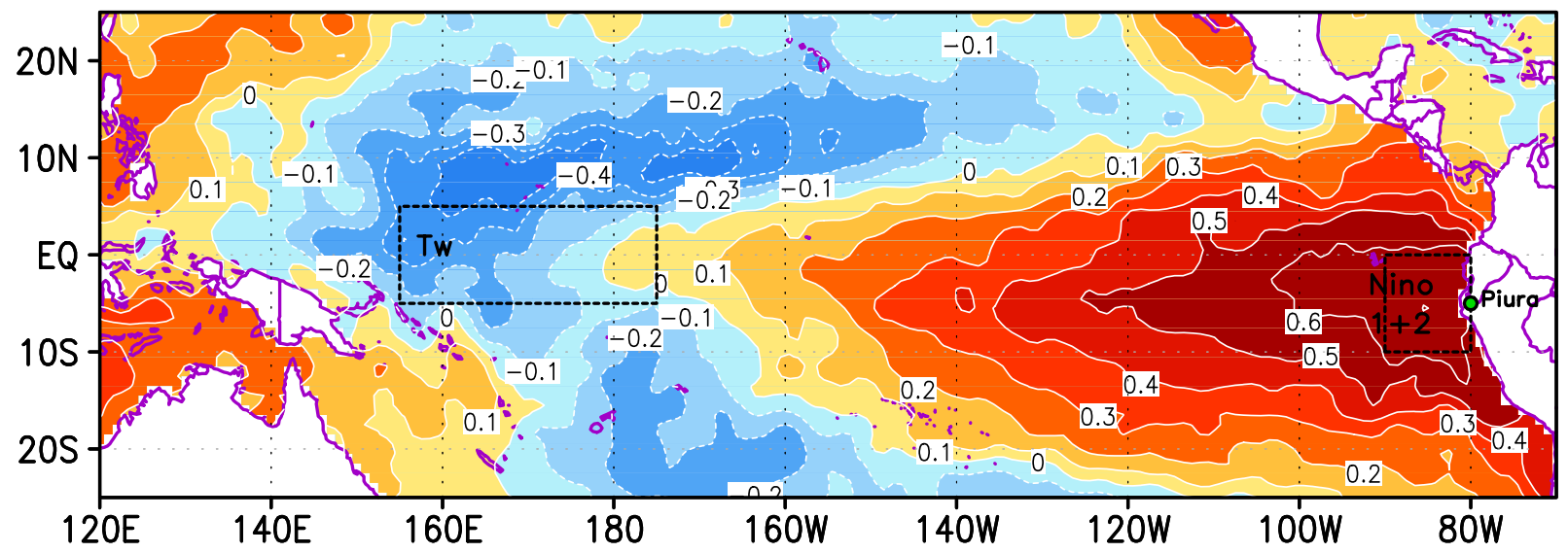

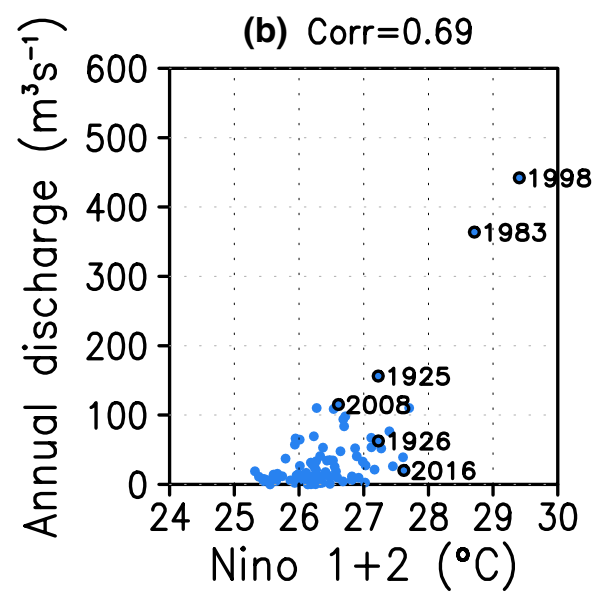

Fig. 11 a Linear correlation between the annual discharge averaged for the Piura river with the February-March SST from HadISST 1.1 (1925-2016). Scatter plots between the same discharge

and Peru in February-April 1925. In situ instrumental records and extensive newspaper reports allowed us to reconstruct the ocean-atmosphere evolution in the tropical Pacific, particularly in the FEP, as well as the large extent of the impacts associated with heavy rainfall and flooding in coastal Peru and Ecuador, which extended as far south as $12^{\circ} \mathrm{S}$.

The $1925 \mathrm{EN}$ event was the one that introduced the concept of El Niño to the scientific community. However, this very strong and archetypical EN event in terms of its FEP signature was restricted to this region and coincided with anomalously cold conditions in the rest of the equatorial Pacific. This "coastal" EN took place in February-April 1925, in the transition from a cool to a warm ENSO state. However, the coastal warming was not associated with the equatorial zonal dynamics that are the essence of ENSO. Instead, in situ hydrographic data in the FEP indicate that the warming was shallow and the tidegauge data at Balboa indicates that sea level was lower and the SST averaged over $\mathbf{b}$ the Niño $1+2$ region, $\mathbf{c}$ the Tw region $\left(155^{\circ} \mathrm{E}-175^{\circ} \mathrm{W}, 5^{\circ} \mathrm{S}-5^{\circ} \mathrm{N}\right)$, as well as with $\mathbf{d}$ the difference between the two (Niño $1+2$ minus Tw)

than normal, so downwelling Kelvin waves were unlikely to have played a significant role in producing the coastal warming. On the other hand, in situ ship-based wind data indicate strong northerly winds that reached $7^{\circ} \mathrm{S}$ on average in February-March 1925, which climatologically only extend to the equator near the coast. The meridional asymmetry in SST was also reversed, i.e. with a warmer southern than northern hemisphere. The ship data also indicates reduced cloudiness, increased sea level pressure, and net wind divergence, north of the equator, and the opposite off northern Peru, indicative of the weakening/strengthening of the ITCZ to the north/south of the equator. The above then indicates a reversal of the north-south asymmetry relative to the equator in the coupled ocean-atmosphere system that includes the ITCZ, meridional wind, and SST.

The abrupt onset of this coastal EN, with the southern ITCZ and northerly anomalies, suggests strong external forcing and/or strong nonlinear coupled feedbacks. Regarding the former, the in situ data indicates that the Panama 

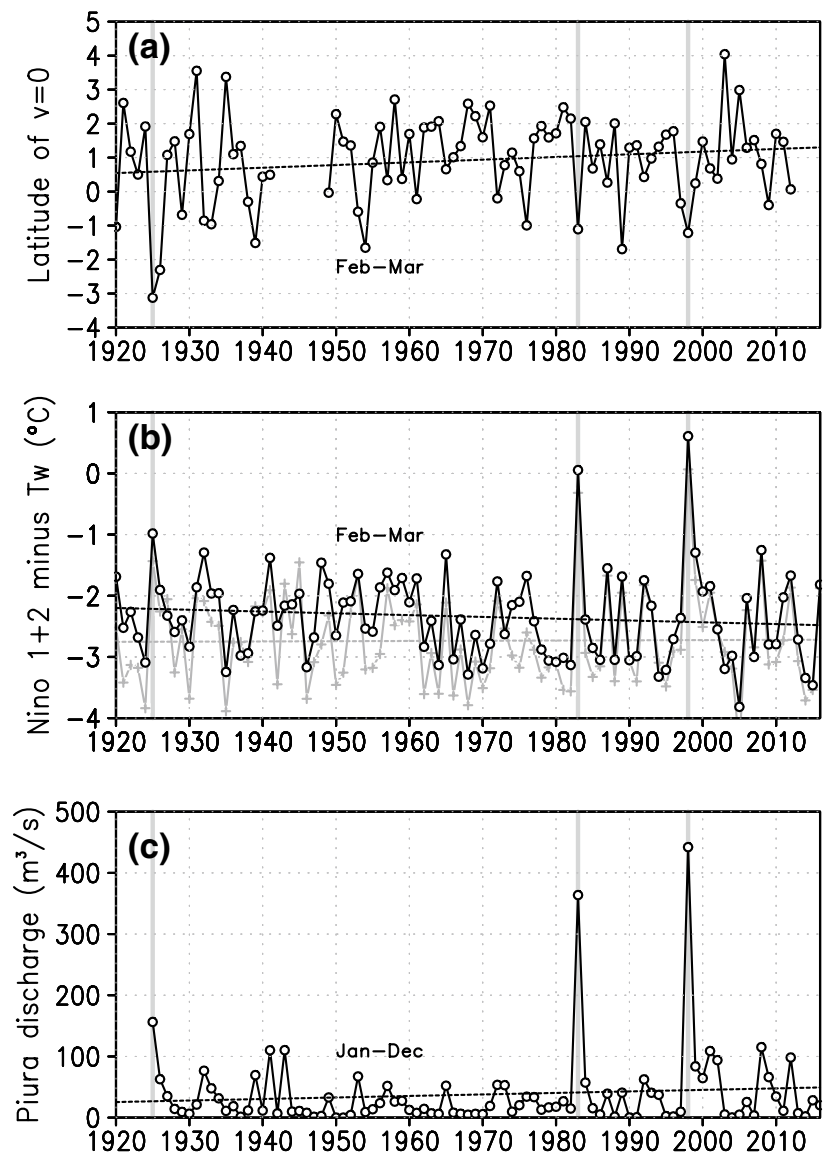

Fig. 12 a Latitude of zero meridional wind along the near-coastal track based on the February-March mean wind from ICOADS, the $\mathbf{b}$ February-March mean Niño $1+2$ minus Tw SST $\left({ }^{\circ} \mathrm{C}\right)$ from HadISST 1.1 (black, circles) and ERSST v3b (grey, crosses) and $\mathbf{c}$ the annual (Jan-Dec) mean Piura river discharge $\left(\mathrm{m}^{3} / \mathrm{s}\right)$. Linear fits are shown dashed. Vertical lines indicate the years 1925, 1983, and 1998

gap jet was not anomalously stronger and that the south Pacific anticyclone was not weaker in this period, indicating that the associated external forcing was not strong. Thus, it seems more likely that the nonlinearity associated with a threshold in SST for the activation of the ITCZ south of the equator was responsible for the abrupt transition, as in the model of Xie and Philander (1994, XP94). The mechanism for the ocean warming probably involved a combination of the wind-evaporation-SST mechanism (XP94) and oceanic southward warm advection, i.e. the enhanced "Corriente del Niño". The existence of this warm countercurrent was shown with ship drift data and is consistent with a calculation of a frictional current driven by the observed northerly winds. To the extent that a nonlinear coupled feedback underlies the onset and retreat of the southern ITCZ, the very strong coastal EN can be described as an enhancement of the insolation-driven seasonal cycle, particularly through the destabilization of the seasonal SST-ITCZ-meridional wind dynamics.
We propose that an important mechanism for destabilizing the ITCZ involves the zonal equatorial SST gradient in the Pacific, particularly the contrast between the SST in the FEP and in the western-central Pacific, as the latter affects the temperature in the free tropical troposphere and, therefore its static stability, as well as the zonal upper air moisture flow in the FEP that affects convection. This is shown to be the case using a river discharge record on the coast of Peru at $5^{\circ} \mathrm{S}$, the climatological latitude of the southern ITCZ band, which shows a strong nonlinear relation with the difference in SST between the FEP and western-central Pacific, with more strongly enhanced discharge when the former is less than $\sim 1.5^{\circ} \mathrm{C}$ colder than the latter. In early 1925, the cold conditions in the central-western Pacific and the warm eastern Pacific both contributed to high river discharges, whereas during the warm ENSO phase the effects of the two regions oppose each other as in 1926 and notably during the strong 2015-16 EN (L'Heureux et al. 2016).

In the context of ENSO diversity, there have been several studies that have classified EN events according to their spatial pattern. But if we focus on those EN events that have very strong impacts on coastal Peru and Ecuador with very high SST and coastal rainfall, we can identify two major types:

- Very strong warm ENSO events, e.g. 1982-83 and 1997-98, that are associated with the zonal dynamics in the equatorial Pacific and a nonlinear Bjerknes feedback that enhances their growth (Takahashi and Dewitte 2016), which are potentially predictable several months in advance,

- Very strong "coastal" EN, e.g. 1891 and 1925, with cold to neutral conditions in the rest of the equatorial Pacific and associated with meridional dynamics in the FEP involving the abrupt enhancement of the ITCZ and warming south of the equator and strong northerly winds. Based on our current knowledge, this type of event is not as predictable as the warm ENSO events.

Further studies will be needed to verify the proposed mechanisms, but this will prove challenging as climate models continue to have strong biases in this region, particularly associated with a warm coastal bias and an excessively strong southern ITCZ, perhaps similar to this very strong coastal EN. In situ data in this region, particularly observations of the atmospheric circulation associated with the southern ITCZ, would be very valuable for the validation of both the mechanisms and the models themselves.

Acknowledgements This study was supported by the ManglaresIGP Project (IDRC 106714) and the Peruvian PP068 program. We thank A. Chang and C. Rojas-Rosas for the "El Comercio" and "El Tiempo" newspaper clippings, respectively, as well as I. Montes and A. Levy for their help acquiring the Arcturus (Beebe 1926) and 
Chicama data, respectively. We thank K. Mosquera, R. Woodman, J. Cole, B. Dewitte, A. Watkins, R. Rodríguez, A. Timmermann, J. Apaéstegui, J. C. Espinoza, and S. Morera for useful discussions. Data analysis and plots were done with GNU Octave and GrADS.

Open Access This article is distributed under the terms of the Creative Commons Attribution 4.0 International License (http:// creativecommons.org/licenses/by/4.0/), which permits unrestricted use, distribution, and reproduction in any medium, provided you give appropriate credit to the original author(s) and the source, provide a link to the Creative Commons license, and indicate if changes were made.

\section{Appendix A: Rainfall and hydrological anomalies in coastal Peru and southern Ecuador}

In this section we report the manifestations of the El Niño along the coasts of southern Ecuador and Peru in the first third of 1925 , when the impacts were the strongest. In the case of Peru, we describe these by regions, as the timing varied substantially as the event progressed southward following the increase in absolute SST (Schott 1931). Particularly, we document the day-to-day variability in detail, illustrating the similarities in the severe impacts associated with heavy rainfall in the different regions, as far south as Lima $\left(12^{\circ} \mathrm{S}\right)$ in the coastal lowlands. Additionally, we highlight the important difference between rainfall in the lowlands and in the mountain slopes, both in timing and magnitude, associated partly to orographic enhancement but also to the differential influences of the FEP and central Pacific SST.

\section{Appendix A.1: Southern coastal Ecuador}

Terneus and Gioda (2006) describe the impacts of the heavy rain and associated flooding around Guayaquil $\left(2.2^{\circ} \mathrm{S}\right)$, in coastal Ecuador, which affected railways, bridges, roads, and telegraph lines, interrupting the exchange of basic products between the coast to the mountain region. In particular, the shortage of salt resulted in riots in the Andean city of Cuenca on April 28.

The annual rainfall in Guayaquil in 1925 was $2556 \mathrm{~mm},{ }^{1}$ more than twice the long-term (1916-2000) average of $1100 \mathrm{~mm}$ and the third largest after the years 1983 and 1998 (3948 and $3512 \mathrm{~mm}$, respectively, Fig. 1b). The monthly data indicates that the heavy rainfall started in January 1925 and lasted through April (Fig. S3b). Although precipitation in 1926 was also high $(1588 \mathrm{~mm})$, it was substantially less than in 1925, and it was contributed primarily by the March 1926 value (Fig. S3b). In nearby Milagro,

\footnotetext{
${ }^{1}$ Due to missing data in June 1925, this is probably slightly underestimated (see Fig. S3b).
}

the difference between 1925 (annual value of $2830 \mathrm{~mm}$ ) and $1926(1937 \mathrm{~mm})$ was more pronounced and the anomalous period in 1925 started later in February (Fig. S3a). At both locations, however, the precipitation in January-March 1926 was comparable to the same season in 1929, considered a non-El Niño year (Quinn et al. 1987; Quinn 1992; Fig. 1a). At the coast, precipitation in Ancon also had high values in February-April 1925 and February-March 1926, weaker than on Guayaquil and Milagro to the east but in this case the 1926 values were substantially higher than in 1929 (Fig. S3c), although 1932 was higher than 1926 but less than 1925 (Sheppard 1933).

\section{Appendix A.2: Tumbes region}

In the Tumbes region (around $3.6^{\circ} \mathrm{S}$ ), near the boundary between the moist tropical and arid climate regimes in northern Peru, in February 1925 there were "torrential rains" and unprecedented levels of the Tumbes river levels and flooding, ${ }^{2}$ as well as two other floods of the city of Tumbes in March and one in April 3. ${ }^{3}$ More precise information is available for Zorritos $\left(3.67^{\circ} \mathrm{S}\right)$, were strong rainfall was observed in January-April 1925 and 1926, particularly in February 1925 and March 1926 (Petersen 1935; Fig. S3d). In Zorritos, the 1926 rainfall was only slightly smaller than in 1925, while 1929 had average rainfall. On the other hand, the Zorritos annual rainfall for 1925 (1524 $\mathrm{mm})$ and $1926(1265 \mathrm{~mm})$ were each approximately 2-3 times smaller than the values from nearby coastal Puerto Pizarro $\left(3.50^{\circ} \mathrm{S}\right)$ and El Salto $\left(3.45^{\circ} \mathrm{S}\right)$ for 1983 (3204 and $4013 \mathrm{~mm}$, respectively) and 1998 (2439 and $3181 \mathrm{~mm}$, respectively; Fig. S6a). We believe that the data of these stations are comparable because the mean annual rainfall for 1962-1982 from Puerto Pizarro $\left(3.50^{\circ} \mathrm{S} ; 194 \mathrm{~mm}\right)$ and El Salto $\left(3.45^{\circ} \mathrm{S} ; 189 \mathrm{~mm}\right)$ are similar to the $1927-1959$ mean from Zorritos (194 mm).

On the other hand, Petersen (1935) reported intense rainfall in El Gurí in 1932 but, since this location is $10 \mathrm{~km}$ up the valley from the city of Tumbes (Woodman 1985), it is probably subjected to orographic enhancement and therefore cannot be compared with Zorritos. This enhancement has been observed in the 1982-83 (Horel and CornejoGarrido 1986; Goldberg et al. 1987) and 1997-98 El Niño (Douglas et al. 2009), associated with westerly flow that produces orographic lifting and triggers convection (Takahashi 2004; Douglas et al. 2009).

It is important to note that most of the February 1925 rainfall in Zorritos was produced in 3 days: February 16

\footnotetext{
${ }^{2}$ El Comercio 1925-04-03, p. 1-2.

${ }^{3}$ El Comercio 1925-04-18 p. 11.
} 
(375 mm), 20 (200 mm), and 14 (100 mm; Fig. 10c), similar to March 1926, in which the three rainiest days were March $4(190 \mathrm{~mm}), 22(134 \mathrm{~mm})$, and $8(115 \mathrm{~mm}$; Petersen 1935). The February 16 rainfall is likely the largest daily rainfall record in northern coastal Peru, as the next value was $313.7 \mathrm{~mm}$ in February 8, 1998, in El Salto, in the mangroves near the border with Ecuador (León 2014), although the reliability of the 1925 values are difficult to assess.

\section{Appendix A.3: Piura region}

The arid Piura region, around $5^{\circ} \mathrm{S}$, is the birthplace of the concept of El Niño and is a region particularly susceptible to large interannual variability in rainfall, from arid conditions to torrential (Carrillo 1893; Eguiguren 1894). For the 1925 rainy season there is substantial available information, albeit scattered. Here we reconstruct the rainfall chronology based primarily on El Comercio and El Tiempo (see Table S2 for the city of Piura) but also on the detailed daily accounts of qualitative rainfall observations in Talara (Murphy 1926) and in Piura ${ }^{4}$ (Table S1). Based on the latter, days with moderate and heavy rainfall are indicated with triangles in Fig. 10d.

The first signs of rain were reported in coastal Talara $\left(4.6{ }^{\circ} \mathrm{C}\right)$ as a spatter of rain in January 19 , with northeasterly wind, and harder in January 27 , with northerly wind (Murphy 1926). Heavy rainfall was first reported near the foothills in the Piura river basin (Chulucanas, Tambogrande, Morropón) in January $31 .^{5}$

The first heavy shower was observed in the city of Piura (lowlands, 5.2 ${ }^{\circ} \mathrm{S}$ ) in February 2 and then on the $7,{ }^{6}$ while heavy rain was also reported in Talara on February 2-4 (Murphy 1926). The flooding of the Chira river also started in February 2, repeatedly affecting Sullana $\left(4.9^{\circ} \mathrm{S}\right)$, where the floods of the 1877-1878 El Niño wiped down forests of large algarrobos (Prosopis pallida). ${ }^{7}$

The daily Piura river discharge presented its first peak of $345 \mathrm{~m}^{3} \mathrm{~s}^{-1}$ in February 10 (Murphy 1926; Fig. 10d). In the evenings of February 12 and 13, heavy rainfall flooded the city of Piura, also affecting the port of Paita, Chulucanas and Tambogrande at the foothills, the Sullana area, ${ }^{8}$ and Talara (Murphy 1926)

\footnotetext{
${ }^{4}$ El Comercio 1925-04-17, p. 8.

5 El Comercio 1925-02-12, p. 3; 1925-02-13, p. 2.

${ }^{6}$ El Comercio 1925-04-17, p. 8.

${ }^{7}$ El Comercio 1925-02-12, p. 3; 1925-02-14, p. 10; 1925-02-21, p. 10.

${ }^{8}$ El Comercio 1925-02-17, p. 1; El Comercio 1925-02-27, p. 2; 1925-04-17, p. 8.
}

In the evening of February 15, the first thunderstorm was reported in the city of Piura ${ }^{9}$, while heavy and moderate rainfall were reported in Sullana ${ }^{10}$ and Talara (Murphy 1926). In Piura, rainfall extended to the following noon. ${ }^{11}$

On February 19, another thunderstorm was reported in Piura, ${ }^{12}$ while on February 20, heavy rain was again reported in Piura, Chulucanas, Tambogrande, and Morropón, and El Comercio refers that "after decades, since 1891, the plains of Castilla are satiated with the plentiful rains that are happenning almost daily" next to the city of Piura. ${ }^{13}$

The Piura river level started rising on February 20, with a discharge of $483 \mathrm{~m}^{3} \mathrm{~s}^{-1}$ in February 21, after which the record stopped (Murphy 1926; Fig. 10d). At the peak of the Piura river swelling on February 23-24, the bridge of the city of Piura was destroyed and several neighborhoods were completely flooded, with the water reported to have reached higher grounds than in the $1891 \mathrm{El}$ Niño. ${ }^{14}$ The above indicates increasing rainfall in the foothills and, between February 23 and 24, violent storms were reported in Chulucanas and Sullana. ${ }^{15}$ Moderately heavy rainfall was reported in Piura on February 22-23. ${ }^{16}$ and intermitent rainfall in Talara on the 23, with strong northerly wind on the 24 with one hour of rain (Murphy 1926), which coincided with unprecedented heavy rainfall in the desertic Sechura further south $\left(5.6^{\circ} \mathrm{S}\right) .{ }^{17}$

On the 27, it rained briefly in Talara (Murphy 1926) but persistingly in Piura on the 27 and $28 .{ }^{18}$ Rainfall in Sullana returned stronger in February $28 .{ }^{19}$ On March 2, rainfall was again strong in Sullana ${ }^{20}$ and Piura, ${ }^{21}$ and intermitent in Talara (Murphy 1926). On March 5-6, heavy rain was reported in Piura, ${ }^{22}$ Talara (Murphy 1926), Sullana, Morropón, Chulucanas, Tambogrande, and other locations, with rain in coastal sites such as Colán, Negritos and Máncora on March 6-7. ${ }^{23}$

\footnotetext{
${ }^{9}$ El Comercio 1925-04-17, p. 8.

10 El Comercio 1925-02-17, p. 1.

11 El Comercio 1925-04-17, p. 8.

12 El Comercio 1925-04-17, p. 8.

13 El Comercio 1925-02-28, p. 6; 1925-04-17, p. 8.

14 El Comercio 1925-03-02, p. 1; 1925-03-06, p. 6; 1925-03-07, p. 3.

15 El Comercio 1925-03-07, p. 3; 1925-04-12 p. 6.

16 El Comercio 1925-04-17, p. 8.

17 El Comercio 1925-04-12 p. 6.

18 El Comercio 1925-04-17, p. 8.

${ }^{19}$ El Comercio 1925-04-12 p. 6.

${ }^{20}$ El Comercio 1925-04-12 p. 6.

${ }^{21}$ El Comercio 1925-04-17, p. 8.

22 El Comercio 1925-04-17, p. 8.

23 El Comercio 1925-03-15 p. 6; 1925-03-24, p. 3.
} 
Rainfall continued daily in Piura during March 8-16, with around $50 \mathrm{~mm}$ accumulated in March 10, reportedly stronger than seen in $1891 .^{24}$ New swelling of the Piura river $\left(790 \mathrm{~m}^{3} \mathrm{~s}^{-1}\right.$ was registered on March 9; Murphy 1926; Fig. 10d) although no flooding was noted. ${ }^{25}$ In Talara, heavy rain was reported in March 8, 10 and 15, the latter two with northern wind and great intensity on the 15 (Murphy 1926). On March 12, persistent early rain flooded Piura again. $^{26}$

In Talara, heavy rain fell from March 18 to 19 (Murphy 1926). In Piura, no rain fell between March 17 and $20,{ }^{27}$ but on March 19, huge swelling of the Piura river was reported, indicating strong rainfall in the foothills and above, with the water level reaching $6.7 \mathrm{~m}$ on March 19-20, dropping to $6.2 \mathrm{~m}$ by March 21 . Fortunately the work done by the authorities and the population prevented serious impacts in Piura, although further downstream in Catacaos the damage was severe. ${ }^{28}$ Additionally, heavy rain fell on Piura on March 21, ${ }^{29}$ and in Chulucanas, torrential rain took place in one hour in either March 20 or $21 .^{30}$

In Talara, strong thunderstorms were reported in March 23-24 and 26, and again heavy rain in March 29-30 with north wind (Murphy 1926). On March 28, heavy rain fell in Piura, albeit briefly, but became extraordinarily strong in March 29-31, allowing people to use boats for transport in flooded parts in the city. Similar rain fell in Catacaos, Paita y Sullana, Tambogrande and Chulucanas. ${ }^{31}$ The Piura river height was 4.60 and $5.25 \mathrm{~m}$ in March 29 and 30, respectively. $^{32}$

On April 1, the rainfall was again very intense in Piura and the following days, April 2-6, continued with heavy rainfall, with a new peak in the level of the Piura river of $5.8 \mathrm{~m}$ on April 4. ${ }^{33}$ Weaker rain fell in Piura on April 14, 17, 18, and 21. In Talara, after April 1, rainfall subsided, with some drizzle (Murphy 1926).

\section{Appendix A.4: Lambayeque region}

In the arid region of Lambayeque, the flooding of the river Zaña is known to have destroyed the city with the same

\footnotetext{
${ }^{24}$ El Comercio, 1925-03-24, p. 6; 1925-04-17, p. 8.

25 El Comercio, 1925-03-24, p. 6.

${ }^{26}$ El Comercio 1925-03-24, p. 6.

27 El Comercio 1925-03-30 p. 1.

${ }^{28}$ El Comercio 1925-03-30, p. 1, 4; El Comercio 1925-04-14, p. 7; 1925-04-17, p. 8.

29 El Comercio $1925-03-30$ p. 1 ; 1925-04-17, p. 8.

30 El Comercio $1925-03-30$ p. 1.

31 El Comercio 1925-04-12 p. 6; 1925-04-17, p. 8.

32 El Comercio 1925-04-12 p. 6.

33 El Comercio 1925-04-15 p. 1,4; 1925-04-17, p. 8.
}

name $\left(6.9^{\circ} \mathrm{S}\right)$ in a single day: March 15,1720 (Nials et al. 1979). Rocca (2000) does a detailed intercomparison of the impacts of the El Niño on several sectors in the Lambayeque region, finding similarities between 1925, 1983, and 1998 in terms of the climate anomalies, as well as in the vulnerability.

In 1925, the first rains were reported in Ferreñafe, in the lowlands between the La Leche/Motupe and Chancay-Lambayeque valleys $\left(6.5^{\circ} \mathrm{S}\right)$, in January $31^{34}$ but starting in February 17 the rain in this location was "terrible" and continuous. ${ }^{35}$ In the city of Chiclayo $\left(6.8^{\circ} \mathrm{S}\right)$, heavy rain was reported for a few hours in an evening somewhere in between February 15 and $17 .{ }^{36}$ In the period of February 15-17, the swelling of rivers Zaña and La Leche destroyed several bridges, ${ }^{37}$ and in February 21 , the flooding of the Motupe river produced damages, particularly of the Zurita creek that "flooded in 1891, but not as much as in this year, in which it has reached few meters of the main square" of Jayanca $\left(6.4^{\circ} \mathrm{S}\right) .{ }^{38}$ On February 22 , the flooding of the Motupe river covered the main square of Morrope $\left(6.5^{\circ} \mathrm{S}\right)$ with half a meter of water. ${ }^{39}$

On March 6-7, very heavy rain fell directly on the lowland cities (Jayanca, Chiclayo, Ferreñafe) and new swelling of several rivers (Zaña, Chancay-Lambayeque and Olmos, and possibly others), producing generalized flooding of towns and cities such as Chiclayo, Lambayeque, Etén, Ferreñafe, Pomalca, Reque, Olmos. ${ }^{40}$ Again, on March 11, very heavy rainfall was reported in Chiclayo, Ferreñafe, and Reque, ${ }^{41}$ and on March 15, there were generalized heavy rain, with thunder and lightning, which was argued to have been previously unseen in this region. ${ }^{42}$

Then, on March 18-20, again "terrible" rainfall and flooding in Eten and Pimentel (both on the coast), Chiclayo, Lambayeque, Olmos. ${ }^{43}$ This was repeated on March 24, with unprecedented heavy rain in Eten and Pimentel

\footnotetext{
${ }_{34}$ El Comercio 1925-05-11, p. 4.

35 El Comercio 1925-05-11, p. 4.

${ }^{36}$ El Comercio 1925-02-18, p. 4.

37 El Comercio 1925-02-28, p. 4

38 El Comercio 1925-02-25, p. 1.

39 El Comercio 1925-03-14, p. 2.

${ }^{40}$ El Comercio $1925-03-25$ p. 4 ; $1925-03-27$, p. 5 ; 1925-03-14, p. 2; 1925-04-13, p. 4.

${ }^{41}$ El Comercio 1925-03-27, p. 4; 1925-04-03, p. 8; El Comercio 1925-04-13, p. 1,4; 1925-05-11, p. 4.

42 El Comercio 1925-05-11, p. 4.

43 El Comercio 1925-03-27, p. 4,5; 1925-03-28, p. 2; 1925-03-30, p. 2 ; 1925-04-30, p. 4; 1925-05-11, p. 4.
} 
(73 $\mathrm{mm}$ in the latter), as well as in Chiclayo and Ferreñafe. ${ }^{44}$

On March 28, the river Chancay-Lambayeque changed its course towards its left margin ${ }^{45}$ and very strong rain fell again on Ferreñafe. ${ }^{46}$ By the end of March and early April, some rainfall was reported in Chiclayo but less intense than before. $^{47}$

The heavy rainfall and the flooding in 1925, produced severe damage to the populated centers. Particularly, destroying $32 \%$ of the houses in Eten and Monsefú, $17 \%$ in Lambayeque, $16 \%$ in Reque, and 6\% in Ferreñafe and Chongoyape (Huertas 2001). As seen in Fig. 1, the annual mean discharge for the river Zaña in $1925\left(23.5 \mathrm{~m}^{3} \mathrm{~s}^{-1}\right)$ was larger than the one for $1983\left(18.1 \mathrm{~m}^{3} \mathrm{~s}^{-1}\right)$ but smaller than for $1998\left(27.8 \mathrm{~m}^{3} \mathrm{~s}^{-1}\right)$, while the value for $1926\left(8.5 \mathrm{~m}^{3} \mathrm{~s}^{-1}\right.$ ) was near normal.

\section{Appendix A.5: La Libertad region}

The region around the city of Trujillo $\left(8.1^{\circ} \mathrm{S}\right)$ is arid, with a total annual rainfall of $10.7 \mathrm{~mm}$ measured at the airport (1983-2003; GRA La Libertad 2010). In 1925, the intense rain and associated flooding produced substantial damage to buildings (e.g. partial destruction of the town of Virú) and agricultural land, although prevention works, started in mid-February 1925, reduced the potential impacts (Zegarra 1926). The heavy rainfall produced substantial damage to the pre-Inca ruins of Chan-Chan and the Huaca of the Sun (Zegarra 1926; Holstein 1927). Although several hydrological stations were destroyed by the floods, we have continuous data for the Chicama and Virú rivers (Fig. 10e), as well as raingauge data from Hacienda Herederos, in the Moche river valley about $12 \mathrm{~km}$ east of Trujillo (Zegarra 1926). The annual mean discharge for river Virú (Reparaz 2013; Fig. 1d) shows similar values for $1925\left(25.3 \mathrm{~m}^{3} \mathrm{~s}^{-1}\right)$ and $1998\left(23.6 \mathrm{~m}^{3} \mathrm{~s}^{-1}\right)$, much larger than in $1983\left(7.0 \mathrm{~m}^{3} \mathrm{~s}^{-1}\right)$ and $1926\left(3.4 \mathrm{~m}^{3} \mathrm{~s}^{-1}\right)$.

In 1925, rain and river flooding was initially reported between February 15 and 20 in the nearby Andean slopes, in the Chicama and Moche valleys, that activated ravines and destroyed bridges and roads ${ }^{48}$ although the Chicama discharge did not present substantial peaks in this period (Fig. 10e).

In March 6, rainfall and the Moche river flooding were reported again inland and by March 7 the heavy rainfall

\footnotetext{
$\overline{44}$ El Comercio $1925-04-03$, p. 8; 1925-04-13, p. 1; 1925-04-13, p. 1; 1925-05-11, p. 4.

45 El Comercio 1925-04-21, p. 7

46 El Comercio 1925-05-11, p. 4.

47 El Comercio 1925-04-08, p. 2; 1925-04-13, p. 4.

48 El Comercio 1925-02-25, p. 1; 1925-02-27, p. 3; 1925-03-01, p. 5.
}

flooded the city of Trujillo itself in one and a half hours, which reminded the locals of the flood of 1891, as well as other coastal towns such as Huanchaco, Salaverry, and Moche. The discharge of the Virú and Chicama rivers rose starting in March 6 (Fig. 10e).

In March 8, rain continued all day in Trujillo and other coastal locations, and by March 9 the rain continued with reduced strength, ${ }^{49}$ although intense thunderstorms were observed in Pacasmayo $\left(7.4^{\circ} \mathrm{S}\right)$ on the $9 .{ }^{50}$ The raingauge in Herederos registered $26 \mathrm{~mm}$ between March 7 and 9 [Zegarra (1926); Murphy (1926) incorrectly reported 226 $\mathrm{mm}]$.

Another period with heavy rain was March 11-16, which were particularly violent in March 14-15, with thunder and lightning in Trujillo, ${ }^{51}$ leading to the front-page headline "The city of Trujillo has been destroyed", ${ }^{2}$ although this was later recognized to have been an exaggeration. The total rainfall measured in Hacienda Herederos for this period was $107.8 \mathrm{~mm}$ (Fig. 10f; Zegarra 1926). The Chicama river had its maximum discharge $\left(530 \mathrm{~m}^{3} \mathrm{~s}^{-1}\right)$ on March 17, while Virú had elevated discharge on March 16-18 (Fig. 10e).

The other major rainy event was in March 24, which in Trujillo was violent and lasted from 3 p.m. to 11 p.m. ${ }^{53}$ Herederos reported rainfall of $28.9 \mathrm{~mm}$, but Zegarra (1926) notes that this did not reflect the intensity of the rain elsewhere. Both the Virú and Chicama river had a peak in discharge in that day, the largest and last for Virú $\left(800 \mathrm{~m}^{3} \mathrm{~s}^{-1}\right.$; Fig. 10e).

The total rainfall in Herederos for March 1925 was $195 \mathrm{~mm}$, almost 80 times the March average of $2.5 \mathrm{~mm}$ (1983-2003) at the Trujillo airport (GRA La Libertad 2010) and much larger than the annual accumulation in 1983 and 1998 (6.4 and $30.8 \mathrm{~mm}$, respectively) also at the airport, indicating orographic enhancement so these sites cannot be directly compared.

\section{Appendix A.6: Ancash region}

In the coastal region of Ancash, the impacts of heavy rainfall in 1925 were severe, particularly around the cities of Chimbote $\left(9.1^{\circ} \mathrm{S}\right)$, Casma $\left(9.5^{\circ} \mathrm{S}\right)$, and Huarmey $\left(10.1^{\circ} \mathrm{S}\right)$. We describe the chronology for the three cities and their surroundings separately.

\footnotetext{
49 El Comercio 1925-03-12, p. 12; 1925-03-15, p. 12; 1925-03-17, p. 1; 1925-03-18 p. 3

50 El Comercio 1925-03-25, p. 5.

51 El Comercio 1925-03-17 Mp.3 2do; 1925-03-18 p. 1; 1925-03-23, p. 2 ; $1925-03-24$ p. 1.

52 El Comercio 1925-03-18 p. 1.

${ }^{53}$ El Comercio 1925-03-27, p. 4; 1925-03-29 p. 2; 1925-04-09 p. 11.
} 
On March 6 and 7, heavy rainfall was reported around Nepeña, near the foothills of the Andes. ${ }^{54}$ On March 9, the port city of Chimbote received rain so heavy that "the flooding, which was generalized, reached in some points up to one meter depth". ${ }^{55}$ Very heavy rainfall, with thunder and lightning, continued in the following days (March 11-15), affecting Chimbote and its surroundings and "causing horror among the inhabitants of that area, not used to phenomena of this nature." 56 In Nepeña, "horrifying" rain fell on March 15, destroying the town of Moro. ${ }^{57}$ Old people in Nepeña indicated that, although heavy rainfall and flooding were also observed in 1871 and 1891, they were not nearly as strong as in 1925 , even though the rains in 1891 were considered calamitous at that time, but those were only three days, while in 1925 the rain had been continuous since March 7. ${ }^{58}$ On March 24, new rain and river flooding were reported in this area. ${ }^{59}$

Around Casma, as late as February 24, 1925, flooding associated with heavy rain and large river swelling destroyed agricultural land and bridges. ${ }^{60}$ On March 8-16, the rainfall in Casma was severe and sustained, except for short breaks. El Comercio reported "terrifying rainfall (...) much larger to those in 1871 and 1891", "not drops but jets of water falling from the sky" and the flooding of the Casma and Sechín rivers, that destroyed roads, bridges, and telegraph lines. ${ }^{61}$ By March 17, the rain around Casma weakened, but the Sechín river floods continued until March $21 .{ }^{62}$ It is interesting that this event was compared to the "strong +" 1871 and "very strong" 1891 , but the "very strong" 1877-1878 El Niño (Quinn et al. 1987) was not mentioned. Although newspapers mentioned flooding in Casma in February 1878 (Aceituno et al. 2009), perhaps they were not as intense as in the other El Niño years mentioned. The heavy rain and floods returned in March 26, with very high levels in the Tabón and Sechín rivers. ${ }^{63}$ In April 3, the Casma port was flooded again by the Tabón river. $^{64}$

The Casma region is of particular interest because a tree-ring precipitation proxy record starting 1906 has been

\footnotetext{
$\overline{54}$ El Comercio 1925-05-02, p. 8; 1925-06-02, p. 1.

55 El Comercio 1925-03-25, p. 5.

56 El Comercio 1925-03-25, p. 5; 1925-03-25, p. 2.

57 El Comercio 1925-04-02, p. 2; 1925-05-02, p. 8; 1925-06-02, p. 1.

58 El Comercio 1925-04-02, p. 2.

59 El Comercio 1925-04-02, p. 2.

${ }^{60}$ El Comercio 1925-02-26, p. 1, 5.

${ }^{61}$ El Comercio, 1925-03-21, p. 7; 1925-03-21, p. 3; 1925-03-29, p. 8; 1925-04-02, p.4; 1925-04-29, p. 4.

62 El Comercio 1925-04-02, p. 4.

${ }^{63}$ El Comercio 1925-03-27, p. 4.

${ }^{64}$ El Comercio 1925-04-04, p. 8.
}

obtained near San Rafael, about $20 \mathrm{~km}$ inland along the Casma river valley (Rodriguez et al. 2005), clearly shows heavy rainfall in the 1925, 1983 and 1998 El Niño events, with the largest signal in 1925 (Fig. 1d). However, the magnitude of the signal must be interpreted with care, since the normal change in tree growth throughout its lifetime could enhance the signals in the earlier part of the record (R. Rodriguez, personal communication).

Heavy rain severely impacted coastal Huarmey $\left(10.1^{\circ} \mathrm{S}\right)$ starting on March 9 and its river starting flooding on the 13 , producting severe damages in the following days. ${ }^{65}$ On March 18, the river flooded the town, leaving it in ruins. ${ }^{66}$ The final balance was that "Huarmey town has disappeared. Some houses have remained in ruins, but worse, there are no inhabitants". 67

\section{Appendix A.7: Lima region}

In the coastal desertic city of Lima $\left(12.1^{\circ} \mathrm{S}\right)$, it is highly unlikely to have heavy rainfall. The second largest event ever recorded was in March 10, 1925, when $12 \mathrm{~mm}$ of rain fell in nine hours (1:30-10:30 a.m.), according to the Unanue Observatory (the largest was $17 \mathrm{~mm}$ of rain in January 16, 1970), much larger than the climatological monthly total for March of $0.5 \mathrm{~mm}$ (Campo de Marte station, 1929-1949). It was reported that the "strength of the rain was such, that the noise produced by the water drops on the roofs and the street, produced a dull and continuous hum, like the blow of a great bellows" and that the rain coincided with "a sensible increase in temperature, like is seen in countries located in the tropics", which had not been seen since $1891 .^{68}$ Meteorological data from the Unanue Observatory indicates that that day was not particularly warm, but that it had the maximum mean relative humidity (86\%) of the January-April 1925 season (Fig. $\mathrm{S} 5 \mathrm{a}, \mathrm{d})$ and near the minimum wind speed $(\leq 2 \mathrm{~m} / \mathrm{s}$; Fig. $\mathrm{S} 5 \mathrm{~g}$ ). We estimate the specific humidity to also have been the maximum of the period, above $16 \mathrm{~g} / \mathrm{kg}$, in those days (Fig. S5c), whereas the climatological March value in Lima is around $13-14 \mathrm{~g} / \mathrm{kg}$ (Enfield 1981). ${ }^{69}$ Interestingly, SST offshore Callao exceeded $26{ }^{\circ} \mathrm{C}$ in March 19-21 (Schott 1931; Fig. 10f), more than a week after the rainy event, suggesting that atmospheric dynamics played an important role in transporting moist air from the north to Lima around

\footnotetext{
${ }^{65}$ El Comercio 1925-03-30, p. 2.

${ }^{66}$ El Comercio 1925-03-30, p. 2; 1925-04-03, p. 1.

${ }^{67}$ El Comercio 1925-04-16, p. 6.

68 El Comercio, 1925-03-12.

${ }^{69}$ Based on a vapor pressure of 21-23 hPa from his Fig. 4 (corrected by a factor of 10).
} 
March 10, which in turn probably helped increase the SST. On the Callao shore, SST increased abruptly even later, in March 27-29 (Fig. 10a).

Although heavy rainfall on the city of Lima itself is highly unlikely, flash floods with debris flow in the Andean valleys to the east, popularly known as huaycos, are common in the rainy season. Huaycos in the Rímac river valley, are very important as they can interrupt the highway (the railway in 1925) that connects Lima to the Mantaro valley to the east, that supplies most of the agricultural produce to Lima, as well as affecting the hydroelectric generation for Lima. Particularly important are the huaycos near the town of Chosica $\left(11.9^{\circ} \mathrm{S}, \sim 900 \mathrm{~m}\right.$ asl $)$, that is highly vulnerable to them.

The first report of El Comercio for the Rímac river in 1925 indicated flooding of the neighborhood of Lima of the same name between February 5 and $8 .^{70}$ On February 16, a large huayco disabled the hydroelectric generation in Yanacoto (3 km downstream from Chosica), interrupting the electricity in most of Lima, as well damaging the railway between kilometers 60 and 93, and a bridge in $\mathrm{km} \mathrm{88,} \mathrm{and}$ producing large landslides. Then, on February 17, two new huaycos occurred near Yanacoto, between $\mathrm{km} 51$ and 53 (between Lima and Chosica). ${ }^{71}$ In the 30 year discharge record for Rímac river at Chosica, the maximum value had been $152 \mathrm{~m}^{3} \mathrm{~s}^{-1}$, but, on February 18, it was $500 \mathrm{~m}^{3} \mathrm{~s}^{-1}$, with mud and rocks, for six hours starting at 9 p.m. ${ }^{72}$ On the 19 , the river swelling damaged the railway at $\mathrm{km} 51$, disconnecting Lima and Chosica, and also flooding the hydroelectric plants in Yanacoto and Chosica, leaving Lima without electricity and clean water. ${ }^{73}$ More than two weeks after (between March 7 and 9), the Rímac river rose again, with several huaycos affecting Chosica. ${ }^{74}$ Curiously, on March 10, when relatively heavy rain fell on Lima, no events were reported to the east at this time. Then, on March 12 and 14, there was again heavy rainfall in Chosica and huaycos between Yanacoto and Chosica, affecting kms 50 and 51 of the railway. ${ }^{75}$ Finally, between March 18 and 20, there was plentiful rain in Santa Eulalia and Otao (7 and $23 \mathrm{~km}$ upstream from Chosica, respectively) that

\footnotetext{
${ }_{70}$ El Comercio 1925-02-09, p. 7.

71 El Comercio 1925-02-18, p. 2; 1925-02-22, p. 2; 1925-03-02, p.3; 1925-03-20, p. 1.

72 El Comercio 1925-03-21, p. 6.

73 El Comercio 1925-02-18, p. 2; 1925-02-22, p. 2; 1925-03-02, p. 3; 1925-03-20, p. 1.

74 El Comercio 1925-03-09, p. 1.

75 El Comercio 1925-03-18, p. 3.
}

resulted in several floods and huaycos, destroying roads, bridges and buildings. ${ }^{76}$

The monthly mean Rimac discharge data from Chosica are missing for March-April 1925 (Reparaz 2013), reflecting the effect of the huaycos on the measurements, but it should be noted that statistically reconstructed data for Rimac (ANA 2010) does not reflect this, probably underestimating the actual values.

According to O'Connor (1988), huaycos have occurred in the Chosica area in the following years: 1834, 1891, 1909, 1915, 1925, 1926, 1936, 1939, 1950, 1952, 1954, $1955,1959,1967,1972,1976,1983,1985,1987$, to which we can add 1998 (CAF 2000). Using this and considering the February-March SST in the Niño $1+2$ region (1915-present, when data is more reliable), we find that years with a positive/negative SST anomaly have 15\%/8\% probability of huaycos in Chosica. That is, warm coastal conditions enhance the probability of huaycos by almost a factor of two relative to cold conditions, but a coastal El Niño does not guarantee their occurrence. The huaycos in Chosica in 1925 , however, were among the most severe on record (O'Connor 1988).

\section{Appendix A.8: Ica region}

In the Ica region, heavy rains and flooding (llapanas) were reported in the February 1-12 near the Andean slopes and the floods affected the Chincha (aka San Juan), Pisco, Ica, and Rio Grande river valleys, including the city of Ica itself $\left(14.1^{\circ} \mathrm{S}\right) .^{77}$ On February 11, rainfall in the city, heavy for this arid region, was observed from 3 p.m. to 2 a.m. ${ }^{78}$ However, the annual mean discharge of the Ica river $\left(13.9^{\circ} \mathrm{S}\right.$; $17.1 \mathrm{~m}^{3} \mathrm{~s}^{-1}$ ) for 1925 (Reparaz 2013), was not extraordinary, within an standard deviation of the mean (12.0 $\left.\mathrm{m}^{3} \mathrm{~s}^{-1}, 1922-1939\right)$. On the other hand, missing discharge data for Chincha river (aka San Juan; $13.4^{\circ} \mathrm{S}$ ) in March-April 1925 (Reparaz 2013), suggests that the flooding disabled the measurements. In 1926, heavy rainfall was also observed in the Ica valley in February 6 and $13^{79}$ and the annual discharge $\left(13.7 \mathrm{~m}^{3} \mathrm{~s}^{-1}\right)$ was lower than in 1925 .

The early timing of the rains and floods in the Ica region in 1925 indicates that these were not associated with high coastal SST, as the analysis of Schott (1931) indicates values below $20{ }^{\circ} \mathrm{C}$ in early February, but to the onset of the Andean rainfall regime that was probably enhanced by the

\footnotetext{
${ }_{76}$ El Comercio 1925-03-27, p. 2; El Comercio 1925-03-24, p. 5.

77 El Comercio $1925-02-10$ p. 6 ; 1925-02-12 p. 4; 1925-02-18 p. 4 ; 1925-02-27 p. 2.

${ }^{78}$ El Comercio $1925-02-27$ p. 2.

79 El Comercio 1926-02-27.
} 
cold central Pacific conditions. This is consistent with the positive correlation between the annual rainfall in the lowlands of Ica and the $E$ (eastern Pacific warming) index and negative correlation between the Andean slopes of Ica and the $C$ (central Pacific) index (Lavado-Casimiro and Espinoza 2014).

\section{Appendix A.9: Arequipa region}

The city of Arequipa $\left(16.4^{\circ} \mathrm{S}\right)$ on the western Andes, at $2412 \mathrm{~m}$ above sea level, had the largest monthly precipitation in its 30 year record (1896-1925; Bailey 1930) in January 1925 (Fig. S3g), as well as the largest January-March mean. January 22-31 was a period of exceptionally heavy rain, reaching $32.5 \mathrm{~mm}$ on the 27, that fell in the Arequipa, Yura, and Vitor districts, not only in the valley but also on the surrounding mountains, leading to the swelling of the Yura, Chili and other rivers, producing floods and destroying roads, railways, agricultural land, houses. ${ }^{80}$ In February 12-13, new torrential rain produced further damages on railways, bridges and properties, particularly great flooding in Yura on the 12, but also affecting the Majes and Vitor valleys. ${ }^{81}$ Finally, after some drier days, heavy rain fell on the city of Arequipa on March 5-6, with a new flood of the Chili river. ${ }^{82}$ The following year, no mention was made of heavy rain in Arequipa, but the 1925-1926 summer was reportedly "exceptionally warm and early". 83

The extreme January 1925 rains in Arequipa could have had some contribution from the coastal warming of about $1{ }^{\circ} \mathrm{C}$ (Fig. 5b), but was most likely associated with the cold conditions in the central Pacific (Lavado-Casimiro and Espinoza 2014). This connection is supported by the linear correlation of -0.38 between the January-March precipitation in Arequipa record and the $C$ index (1896-1925), while it is only -0.07 with $E$. However, the variance explained by this correlation is not high enough to attribute the 1925 rainfall exclusively to the ENSO anomalies. Interestingly, during the January 1925 rains, it was reported that "every day, after noon, on the horizon towards the coast, threatening clouds appear that pushed by the wind, originates between 3 and 4 in the afternoon the strong rain that for days we have been routinely enduring". ${ }^{84}$ Since the region of Arequipa where these rain occurred is on the

\footnotetext{
${ }^{80}$ El Comercio 1925-02-03, p. 3; El Comercio 1925-02-04, p. 4; 1925-02-05, p. 8; 1925-02-09, p. 1 ; 1925-02-11, p. 2 ; 1925-02-17, p. 2; 1925-02-26, p. 9; 1925-02-27, p. 3.

${ }^{81}$ El Comercio 1925-02-14, p. 1; 1925-02-25, p. 2; 1925-02-26, p. 8; 1925-02-27, p. 3.

82 1925-03-12, p. 4.

83 El Comercio 1925-06-09, p. 2.

84 El Comercio 1925-02-09, p. 1.
}

western side of the Andes, this suggests that the moisture source for the rain could have been the Pacific. The diurnal moisture variability in Arequipa appears to be associated with the valley breeze circulation on the western slope of the Andes (Falvey and Garreaud 2005), which was perhaps enhanced by the tropospheric destabilization associated with the cold central Pacific (Sect. 3.2). On the other hand, the main factor controlling the rainfall variability in the central Andes associated with ENSO appears to be the upper-air zonal wind that modulates the moisture inflow from the Amazon (Garreaud and Aceituno 2001).

\section{Appendix B: Reconstruction of Piura rainfall and discharge}

The rainfall and river discharge records in $\operatorname{Piura}^{85}\left(5.2^{\circ} \mathrm{S}\right.$, $80.6^{\circ} \mathrm{W}, 40 \mathrm{~m}$ asl) are important measures of El Niño in Peru (e.g. Deser and Wallace 1987) but the former did not have data for 1925, while the latter misses key data during the peak of the 1925 El Niño. In this section we use the information we have compiled to provide estimations to complete these records.

We analyzed reports of rainfall in the city of Piura between February and April 1925 in both El Comercio and El Tiempo newspapers and classified the rainy days in terms of their intensity and found a total of 10 strong, 28 moderate and 7 weak rainy days (Fig. 10d, Table S2). Woodman (1985) did a similar analysis for this same period and, by assigning rainfall values of 20 and $60 \mathrm{~mm}$ to the equivalent of our moderate and strong days he estimated a total annual accumulation of $1200 \mathrm{~mm}$. By repeating this calculation with our own list (neglecting weak rainy days), we obtained $1280 \mathrm{~mm}$, indicating that our classifications were similar. However, a raingauge in the city of Piura measured $327 \mathrm{~mm}$ between March 7 and April $1^{86}$ and this calculation produces $580 \mathrm{~mm}$ for this same time period. A closer match is found if we assume that the moderate and strong rainy days correspond to amounts of 10 and $40 \mathrm{~mm}$, which approximately matches the average values for the city of Piura in the dry and rainy day composites of Douglas et al. (2009) for the 1997-1998 El Niño (note that "dry" means less rainy in this context). In this case, we find 350 $\mathrm{mm}$ for the raingauge period and $760 \mathrm{~mm}$ for February-April 1925 (that we consider valid for the full calendar year as well), with the corresponding monthly values of 250,370 , and $140 \mathrm{~mm}$. Our estimate is substantially lower than the one of Woodman (1985), but it is still the largest

\footnotetext{
85 http://research.jisao.washington.edu/data_sets/piura.

${ }^{86}$ El Comercio 1925-04-17, p. 8.
} 
value in the record after the ones for $1983(2387 \mathrm{~mm})$ and 1998 (1721 mm; Fig S6).

We fitted a rating curve between the Piura river water height $(z)$ and discharge $(Q)$ data provided by Murphy (1926) for February-March $1925\left(Q \approx 52.0 z^{1.70}\right)$. We then applied this relation to other water height measurements collected from El Tiempo newspaper to complete the discharge series (Fig. 10d). For instance, the maximum peak discharge in March 19 was estimated as $1351 \mathrm{~m}^{3} \mathrm{~s}^{-1}$, which is $40 \%$ of the maximum value observed in 1998 (3367 $\mathrm{m}^{3} \mathrm{~s}^{-1}$ ), corresponding to April 1 of that year. Some gaps, however, still remained. Of particular relevance is the discharge peak on February 24 (see Appendix A.3), which we roughly estimated as the value halfway between the peaks of March 19 and April 6. Afterwards, we completed the remaining missing data with linear interpolation, noting that measurements restarted on May 9 after a long gap in April, and calculated the monthly means. The resulting February, March, and April 1925 means are 303, 693, and $606 \mathrm{~m}^{3} \mathrm{~s}^{-1}$, respectively. Using these values to complete the 1925 record, we obtain an annual mean of $156 \mathrm{~m}^{3} \mathrm{~s}^{-1}$ for 1925, the third largest in the record after the year 1998 (442 $\left.\mathrm{m}^{3} \mathrm{~s}^{-1}\right)$ and $1983\left(364 \mathrm{~m}^{3} \mathrm{~s}^{-1}\right.$; Figs. 12c, S6). In contrast, the value for 1926 was $63 \mathrm{~m}^{3} \mathrm{~s}^{-1}$.

\section{References}

Aceituno P, Prieto MR, Solari M, Martínez AG, Poveda G, Falvey M (2009) The 1877-1878 El Niño episode: associated impacts in South America. Clim Change. doi:10.1007/s10584-008-9470-5

Alory G, Maes C, Delcroix T, Reul N, Illig S (2012) Seasonal dynamics of sea surface salinity off Panama: the far Eastern Pacific fresh pool. J Geophys Res: Oceans 117(C4):C04028

Autoridad Nacional del Agua (ANA) (2010) Estudio Hidrológico y Ubicación de la Red de Estaciones Hidrométricas en la Cuenca del Río Rímac, 2, 134 pp

Bailey SI (1930) Observations made at the Arequipa station 18961925. Ann Astron Obs Harvard Coll 87(2A):179-217

Battisti DS, Sarachik ES, Hirst AC (1999) A consistent model for the large-scale steady surface atmospheric circulation in the tropics. J Clim 12(10):2956-2964

Beebe W (1926) The Arcturus oceanographic expedition. Zoologica $8: 1-45$

Belmadani A, Echevin V, Codron F, Takahashi K, Junquas C (2014) What dynamics drive future wind scenarios for coastal upwelling off Peru and Chile? Clim Dyn 43(7):1893-1914. doi:10.1007/ s00382-013-2015-2

Bendix J, Trachte K, Palacios E, Rollenbeck R, Göttlicher D, Nauss T, Bendix A (2011) El Niño meets La Niña-anomalous rainfall patterns in the "traditional" El Niño region of southern Ecuador. Erdkunde 65(2):151-167

Berry E (1927) Meteorological observations at Negritos, Peru, December 1924, to May, 1925. Mon Weather Rev 55:75-78

Bjerknes J (1969) Atmospheric teleconnections from the equatorial Pacific. Mon Weather Rev 97(3):163-172

CAF (Corporación Andina de Fomento) (2000) El Fenómeno El Niño 1997-1998. Memoria, Retos y Soluciones, vol 5, p 293
Capotondi A, Wittenberg AT, Newman M, Di Lorenzo E, Yu JY, Braconnot P, Cole P, Dewitte B, Giese B, Guilyardi E, Jin FF, Karnauskas K, Kirtman B, Lee T, Schneider N, Xue Y, Yeh SW (2015) Understanding ENSO diversity. Bull Amer Met Soc 96(6):921-938. doi:10.1175/BAMS-D-13-00117.1

Cardone V, Greenwood JG, Cane MA (1990) On trends in historical marine wind data. J Clim 3:113-127

Carranza L (1891) Contra-corriente maritima observada en Paita y Pacasmayo. Bol Soc Geogr Lima 1(9):344-345

Carrillo CN (1893) Hidrografía oceánica. Bol Soc Geogr Lima, pp $72-110$

Chang A (2014) La cobertura periodística del Fenómeno El Niño de 1925-1926 en el diario El Comercio de Lima. Masters Thesis in History, Pontificia Universidad Católica del Perú

Chiang JCH, Sobel AH (2002) Tropical tropospheric temperature variations caused by ENSO and their influence on the remote tropical climate. J Clim 15:261-2630

Chiodi A, Harrison D, Vecchi GA (2014) Subseasonal atmospheric variability and El Niño waveguide warming: observed effects of the Madden-Julian oscillation and westerly wind events. J Clim 27(10):3619-3642

Clement AC, DiNezio PN, Deser C (2011) Rethinking the oceans role in the Southern Oscillation. J Clim. doi:10.1175/2011J CLI3973.

Compo G, Whitaker J, Sardeshmukh P (2006) Feasibility of a 100year reanalysis using only surface pressure data. Bull Am Metereol Soc 87(2):175-190. doi:10.1175/BAMS-87-2-175

Compo GP, Whitaker JS, Sardeshmukh PD, Matsui N, Allan RJ, Yin $\mathrm{X}$, Gleason BE, Vose RS, Rutledge G, Bessemoulin P, Bronnimann S, Brunet M, Crouthamel RI, Grant AN, Groisman PY, Jones PD, Kruk MC, Kruger AC, Marshall GJ, Maugeri M, Mok HY, Nordli X, Ross TF, Trigo RM, Wang XL, Woodruff SD, Worley SJ (2011) The twentieth century reanalysis project. QJRMS 137:1-28. doi:10.1002/qj.776

Cucalon E (1987) Oceanographic variability off Ecuador associated with an El Niño event in 1982-1983. J Geophys Res 92(C13):14309-14322

Cushman GT (2004) Enclave vision: foreign networks in Peru and the internationalizaiton of El Niño research during the 1920s. Hist Meteorol 1:65-74

Deser C, Wallace JM (1987) El Niño events and their relation to the Southern Oscillation: 1925-1986. J Geophys Res 92:14189-14196

Deser C, Phillips AS, Alexander MA (2010) Twentieth century tropical sea surface temperature trends revisited. Geophys Res Lett 37:L10701. doi:10.1029/2010GL043321

Dewitte B (2000) Sensitivity of an intermediate ocean-atmosphere coupled model of the tropical Pacific to its oceanic vertical structure. J Clim 13:2363-2388

Dewitte B, Takahashi K (2016) Diversity of moderate El Niño events evolution: role of air-sea interactions in the eastern tropical Pacific. Clim Dyn (in review)

Douglas M, Mejia J, Ordinola N, Boustead J (2009) Synoptic variability of rainfall and cloudiness along the coasts of northern Peru and Ecuador during the 1997-8 El Niño event. Mon Weather Rev 137:116-136. doi:10.1175/2008MWR2191.1

Eguiguren V (1894) Las lluvias en Piura. Bol Soc Geogr Lima $4: 241-258$

Enfield DB (1981) Thermally driven wind variability in the planetary boundary layer above Lima, Peru. J Geophys Res 86(C3):2005-2016

Falvey M, Garreaud RD (2005) Moisture variability over the South American Altiplano during the South American low level jet experiment (SALLJEX) observing season. J Geophys Res 110(D22):D22105 doi:10.1029/2005JD006152 
Garcés-Vargas J, Schneider W, Abarca del Río R, Martínez R, Zambrano E (2005) Inter-annual variability in the thermal structure of an oceanic time series station off Ecuador (19902003) associated with El Niño events. Deep-Sea Res I. doi:10.1016/j. dsr.2005.05.008

Garreaud RD, Aceituno P (2001) Interannual rainfall variability over the South American altiplano. J Clim 14:2779-2789

Giese B, Ray S (2011) El Niño variability in simple ocean data assimilation (SODA), 1871-2008. J Geophys Res 116(C2):C02024. doi:10.1029/2010JC006695

Goldberg RA, Tisnado G, Scofield RA (1987) Characteristics of extreme rainfall events in northwestern Peru during the 1982 1983 El Niño period. J Geophys Res 92(C13):14225-14241

GRA La Libertad (2010) La Libertad: Clima y Ríos en Cifras. Estadísticas de Seis Décadas, p 67

Graham NE, Barnett TP (1987) Sea surface temperature, surface wind divergence, and convection over tropical oceans. Science 238(4827):657-659

Harrison DE, Larkin NK (1998) El Niño-Southern Oscillation sea surface temperature and wind anomalies, 1946-1993. Rev Geophys 36(3):353-399

Holstein O (1927) Chan-Chan: capital of the Great Chimu. Geogr Rev 17(1):36-61

Horel JD (1986) Cornejo-Garrido AG (1986) Convection along the coast of northern Peru during 1983: spatial and temporal variation of clouds and rainfall. Mon Weather Rev 114:2091-2105

Huaman L, Takahashi K (2016) The vertical structure of the Eastern Pacific ITCZs and associated circulation using the TRMM precipitation Radar and in situ data. Geophys Res Lett 43:8230-8239. doi:10.1002/2016GL068835

Huertas L (2001) Diluvios andinos: a través de las fuentes documentales. Pontificia Universidad Católica del Perú

Jáuregui YR, Takahashi K (2017) Simple physical-empirical model of the precipitation distribution in the tropical oceans and the effects of climate change. Clim Dyn (in review)

Johnson N, Xie SP (2010) Changes in the sea surface temperature threshold for tropical convection. Nat Geosci 3:842. doi:10.1038/ ngeo1008

Karnauskas K, Busalacchi A, Murtugudde R (2008) Low-frequency variability and remote forcing of gap winds over the east Pacific warm pool. J Clim 21(19):4901-4918. doi:10.1175/2008J CLI1771.1

Kousky VE, Kayano MT (1994) Principal modes of outgoing longwave radiation and 250-mb circulation for the South American sector. J Clim 7(7):1131-1143

Lavado-Casimiro W, Espinoza JC (2014) Impactos de El Niño y La Niña en las lluvias del Perú (1965-2007). Rev Bras Meteor 29(2):171-182

León KB (2014) Análisis espacio-temporal de las precipitationes y caudales durante los eventos El Niño (1982-83 y 1997-98) en la costa norte peruana. Thesis, Agric. Eng, Universidad Nacional Agraria La Molina, Peru, p 146

L'Heureux ML, Takahashi K, Watkins AB, Barnston AG, Becker EJ, Di Liberto TE, Gamble F, Gottschalck J, Halpert MS, Huang B, Mosquera-Vásquez K, Wittenberg AT (2016) Observing and Predicting the 2015-16 El Niño. Bull Am Meteorol Soc. doi:10.1175/BAMS-D-16-0009.1

Lindzen RS, Nigam S (1987) On the role of sea surface temperature gradients in forcing low-level winds and convergence in the tropics. J Atmos Sci 44(17):2418-2436

Morón O (2011) Climatología de la salinidad superficial del mar frente a la costa peruana. 1960-2008. Inf IMARPE 38(1):7-39

Murphy RC (1926) Oceanic and climatic phenomena along the west coast of South America during 1925. Geogr Rev 16:26-54
Nials FL, Deeds EE, Moseley ME, Pozorski SG, Pozorksi TG, Feldman R (1979) El Niño: the catastrophic flooding of coastal Peru. Field Museum Nat Hist Bull 50(7):4-14, (8):4-10

Neelin J, Battisti DS, Hirst AC, Jin FF, Wakata Y, Yamagata T, Zebiak S (1998) ENSO theory. J Geophys Res 103(C7):14261-14290

Oerder V, Colas F, Echevin V, Codron F, Tam J, Belmadani A (2015) Peru-Chile upwelling dynamics under climate change. J Geophys Res. doi:10.1002/2014JC010299

O’Connor H (1988) Investigación del Huayco de Chosica 1987, sus efectos y medidas de mitigación. Thesis in Civil Engineering, Universidad Nacional de Ingeniería, Lima, 99 pp

Perigaud C, Melin F, Cassou C (2000) ENSO simulated by intermediate coupled models and evaluated with observations over 1970-98. Part I: Role of the off-equatorial variability. J Clim 13:16051634

Petersen G (1935) Estudios climatológicos del noroeste peruano. Bol Soc Geol Peru VII:1-141

Philander SGH, Pacanowski RC (1981) The oceanic response to cross-equatorial winds (with application to coastal upwelling in low latitudes). Tellus 33:201-210

Quinn WH, Neal VT, Antunez de Mayolo SE (1987) El Niño occurrences over the past four and a half centuries. J Geophys Res 92(C13):14449-14461

Quinn WH (1992) A study of Southern Oscillation-related climatic activity for AD 622-1900 incorporating Nile River flood data. In: Diaz HF, Markgraf V (eds) El Niño historical and paleoclimatic aspects of the Southern Oscillation. Cambridge Univ. Press, Cambridge, pp 119-149

Ramos Y (2014) Estimación del efecto del cambio climático en la precipitación en la costa norte del Peruú usando simulaciones de modelos climáticos globales. Thesis, Meteor. Eng, Universidad Nacional Agraria La Molina, Peru, p 168

Rasmusson EM, Carpenter TH (1982) Variations in tropical sea surface temperature and surface wind fields associated with the Southern Oscillation/El Niño. Mon Weather Rev 110:354-384

Rayner NA, Parker DE, Horton EB, Folland CK, Alexander LV, Rowell DP, Kent EC, Kaplan A (2003) Global analyses of sea surface temperature, sea ice, and night marine air temperature since the late nineteenth century. J Geophys Res 108(D14):4407. doi:10.1 029/2002JD002670

Reparaz G (2013) Los Ríos de la Zona Árida Peruana. Universidad de Piura, Peru/Institut Cartogràfic de Catalunya, Spain, 352 pp

Rocca L (2000) Impactos de "El Niño" en el sector rural: Lambayeque (siglo XX). SEPIA VIII-Mesas Regionales, p 57

Rodriguez R, Mabres A, Luckman B, Evans M, Masiokas M, Ektvedt TM (2005) "El Niño" events recorded in dry-forest species of the lowlands of northwest Peru. Dendrochronologia 22:181-186. doi:10.1016/j.dendro.2005.05.002

Rojas-Rosas C (2014) La fotografía como elemento informativo del diario "El Tiempo" de Piura: Evolución de uso en la cobertra del fenómeno "El Niño" de 1925 y 1983. Thesis, Communications, Universidad de Piura

Ropelewski CF, Jones PD (1987) An extension of the Tahiti-Darwin southern oscillation index. Mon Weather Rev 115:2161-2165

Schaeffer MB, Bishop YMM, Howard GV (1958) Some aspects of upwelling in the Gulf of Panama. Inter Am Trop Tuna Comm Bull 3(2):79-132

Schott G (1931) Der Peru-Strom und seine nördlichen Nachbargebiete in normaler und anormaler Ausbildung. Ann Hydrogr Mar Meteor 59, 161-169, 200-213, 240-257. Translated to Spanish in Bol Cia Admin Guano, IX, 3-4, 65-110 (1933)

Sheppard G (1930) Notes on the climate and physiography of southwestern Ecuador. Geogr Rev 20(3):445-453

Sheppard G (1933) The rainy season of 1932 in southwestern Ecuador. Geogr Rev 23(2):210-216 
Smith T, Reynolds R, Peterson T, Lawrimore J (2008) Improvements to NOAAs historical merged land-ocean surface temperature analysis (1880-2006). J Clim 21(10):2283-2296

Takahashi K (2004) The atmospheric circulation associated with extreme rainfall events in Piura, Peru, during the 1997-1998 and 2002 El Niño events. Ann Geophys 22:3917-3926

Takahashi K (2005) The annual cycle of heat content in the Peru Current region. J Clim 18:4937-4954

Takahashi K, Dewitte B (2016) Strong and moderate nonlinear El Niño regimes. Clim Dyn. doi:10.1007/s00382-015-2665-3

Takahashi K, Montecinos A, Goubanova K, Dewitte B (2011) ENSO regimes: reinterpreting the canonical and Modoki El Niño. Geophys Res Lett 38:L10704. doi:10.1029/2011GL047364

Terneus A, Gioda A (2006) In search of colonial El Niño events and a brief history of meteorology in Ecuador. Adv Geosci 6:181-187. doi:10.5194/adgeo-6-181-2006

Trenberth KE (1997) The definition of El Niño. Bull Am Meteorol Soc 78(12):2771-2777

Vecchi GA, Soden BJ (2007) Effect of remote sea surface temperature change on tropical cyclone potential intensity. Nature 450(7172): 1066-1070

Vuille M, Bradley RS, Keimig F (2000) Interannual climate variability in the Central Andes and its relation to tropical Pacific and Atlantic forcing. J Geophys Res: Atmos 105(D10):12447-12460

Walker GT (1924) Correlation in seasonal variations of weather. IX. A further study of world weather. Mem India Meteorol Dep 24(9):275-333

Wallace JM, Rasmusson EM, Mitchell TP, Kousky VE, Sarachik ES, von Storch H (1998) On the structure and evolution of ENSOrelated climate variability in the tropical Pacific: lessons from TOGA. J Geophys Res 103(C7):14241-14259

Wang B, Wang Y (1999) Dynamics of the ITCZ-equatorial cold tongue complex and causes of the latitudinal climate asymmetry. J Clim 12:1830-1847

Woodman RF (1985) Recurrencia del fenómeno del Niño con intensidad comparable a la del Niño 1982-1983. El Fenómeno El Niño,
CONCYTEC, Ciencia, Tecnología y Agresión Ambiental, pp 301-332

Woodman RF (1999) Modelo estadístico de pronóstico de las precipitaciones en la costa norte del Peru. El Fenómeno El Niño. Investigación para una prognosis, 1er encuentro de Universidades del Pacíifico Sur: Memoria, pp 93-108

Woodruff SD, Worley SJ, Lubker SJ, Ji Z, Freeman JE, Berry DI, Brohan P, Kent EC, Reynolds RW, Smith SR, Wilkinson C (2011) ICOADS Release 2.5: extensions and enhancements to the surface marine meteorological archive. Int J Climatol 31(7):951967. doi:10.1002/joc. 2103

Wooster WS (1980) Early observations and investigations of El Niño: the event of 1925. Oceanography: the past. Springer, New York, pp 629-641

Worley SJ, Woodruff SD, Reynolds RW, Lubker SJ, Lott N (2005) ICOADS release 2.1 data and products. Int J Climatol 25:823842. doi:10.1002/joc. 1166

Wyrtki K (1975) El Niño-the dynamic response of the equatorial Pacific Ocean to atmospheric forcing. J Phys Oceanogr 5:572-584

Xie SP, Philander SGH (1994) A coupled ocean-atmosphere model of relevance to the ITCZ in the eastern Pacific. Tellus 46A:340-350

Yulaeva E, Wallace JM (1994) The signature of ENSO in global temperature and precipitation fields derived from the microwave sounding unit. J Clim 7:1719-1736

Zebiak SE, Cane MA (1987) A model El Niño-Southern Oscillation. Mon Weather Rev 115:2262-2278

Zegarra JM (1926) Las lluvias y avenidas extraordinarias de 1925 y su influencia sobre la agricultura del departamento de La Libertad

Zhang X, Liu H, Zhang M (2015) Double ITCZ in coupled oceanatmosphere models: from CMIP3 to CMIP5. Res Lett Geophys. doi:10.1002/2015GL065973

Zorell F (1929) La corriente del Niño en 1925. Bol Soc Geogr Lima XLVI:1-18 